\title{
Submarine landslides of the Mediterranean Sea: Trigger mechanisms, dynamics, and frequency-magnitude distribution
}

\author{
Roger Urgeles ${ }^{1}$ and Angelo Camerlenghi ${ }^{2}$ \\ Received 10 January 2013; revised 17 November 2013; accepted 26 November 2013; published 26 December 2013.
}

[1] Submarine landslides are ubiquitous along Mediterranean continental margins. With the aim of understanding mass-wasting processes and related hazard at the scale of a large marine basin encompassing multiple geological settings, we have compiled data on their geometry, age, and trigger mechanism with a geographic information system. The distribution of submarine landslides in the Mediterranean reveals that major deltaic wedges have a higher density of large submarine landslides, while tectonically active margins are characterized by relatively small failures. In all areas, landslide size distributions display power law scaling for landslides $>1 \mathrm{~km}^{3}$. We find consistent differences on the exponent of the power law $(\theta)$ depending on the tectonic setting. Available age information suggests that failures exceeding $1000 \mathrm{~km}^{3}$ are infrequent and may recur every $\sim 40 \mathrm{kyr}$. Smaller failures that can still cause significant damage might be relatively frequent (failures $>1 \mathrm{~km}^{3}$ may recur every 40 years). The database highlights that our knowledge of submarine landslide activity with time is limited to a few tens of thousands of years. Available data suggest that submarine landslides may preferentially occur during lowstand periods, but no firm conclusion can be made on this respect, as only 70 landslides (out of 696 in the database) have relatively accurate age determinations. The temporal pattern and changes in frequency-magnitude distribution suggest that sedimentation patterns and pore pressure development have had a major role in triggering slope failures and control the sediment flux from mass wasting to the deep basin.

Citation: Urgeles, R., and A. Camerlenghi (2013), Submarine landslides of the Mediterranean Sea: Trigger mechanisms, dynamics, and frequency-magnitude distribution, J. Geophys. Res. Earth Surf., 118, 2600-2618, doi:10.1002/2013JF002720.

\section{Introduction}

[2] Submarine landslides have fascinated researchers worldwide for their exceptional size, the very gentle slopes on which they occur [Hühnerbach et al., 2004], variety of emplacement styles, and ensuing implications for geohazard assessment. Compared to the subaerial environment, the marine environment bears some unique peculiarities that are responsible for many of the characteristics of submarine landslides. Amongst those are the following:

[3] 1. the widespread condition of full saturation, with the exception of localized presence of free gas, mainly methane from organic matter decay, particularly in shallow waters;

[4] 2. the load imposed by the water column, which might have disastrous effects in case of unloading of low-permeability gas-charged sediments [Vanoudheusden et al., 2004];

Additional supporting information may be found in the online version of this article.

${ }^{1}$ Institut de Ciències del Mar (CSIC), Barcelona, Spain.

${ }^{2}$ OGS Istituto Nazionale di Oceanografia e di Geofisica Sperimentale, Trieste, Italy.

Corresponding author: R. Urgeles, Institut de Ciències del Mar (CSIC), Pg. Marítim de la Barceloneta, 37-49, 08003 Barcelona, Spain.

(urgeles@icm.csic.es)

(C)2013. American Geophysical Union. All Rights Reserved.

2169-9003/13/10.1002/2013JF002720
[5] 3. the differences in sediment types and their physical properties [Tanaka and Locat, 1999; Volpi et al., 2003];

[6] 4. the occurrence of unique environmental stresses (e.g., tides, surface waves, and internal waves);

[7] 5. slopes suffer much localized erosion and groundwater conditions are relatively homogeneous over large areas, as opposed to emerged slopes that are frequently compartmented by erosional features and groundwater conditions are not homogenous;

[8] 6. seafloor water temperatures and pressure induced by the water column allow formation of gas hydrates which alter the bulk physical properties of the sediments [Sultan et al., 2004, 2007] and are subject to phase change throughout the periods of climate and oceanographic variability;

[9] 7. submerged slopes allow phenomena such as hydroplaning to occur [Mohrig et al., 1998; De Blasio et al., 2006] after initiation of failure, resulting in debris flows with extremely large runout on slopes with gradient as low as $<1^{\circ}$ [Masson, 1994];

[10] 8. finally, perturbation of the fluid-free surface induced by rapid displacement of the landslide mass may be responsible for the generation of tsunami waves [Ward, 2001; Okal and Synolakis, 2004; Harbitz et al., 2006; Watts et al., 2003].

[11] The Mediterranean is a geologically complex area (Figure 1) with a large diversity of geological environments: back-arc extension [e.g., Calvert et al., 2000; Jolivet and 


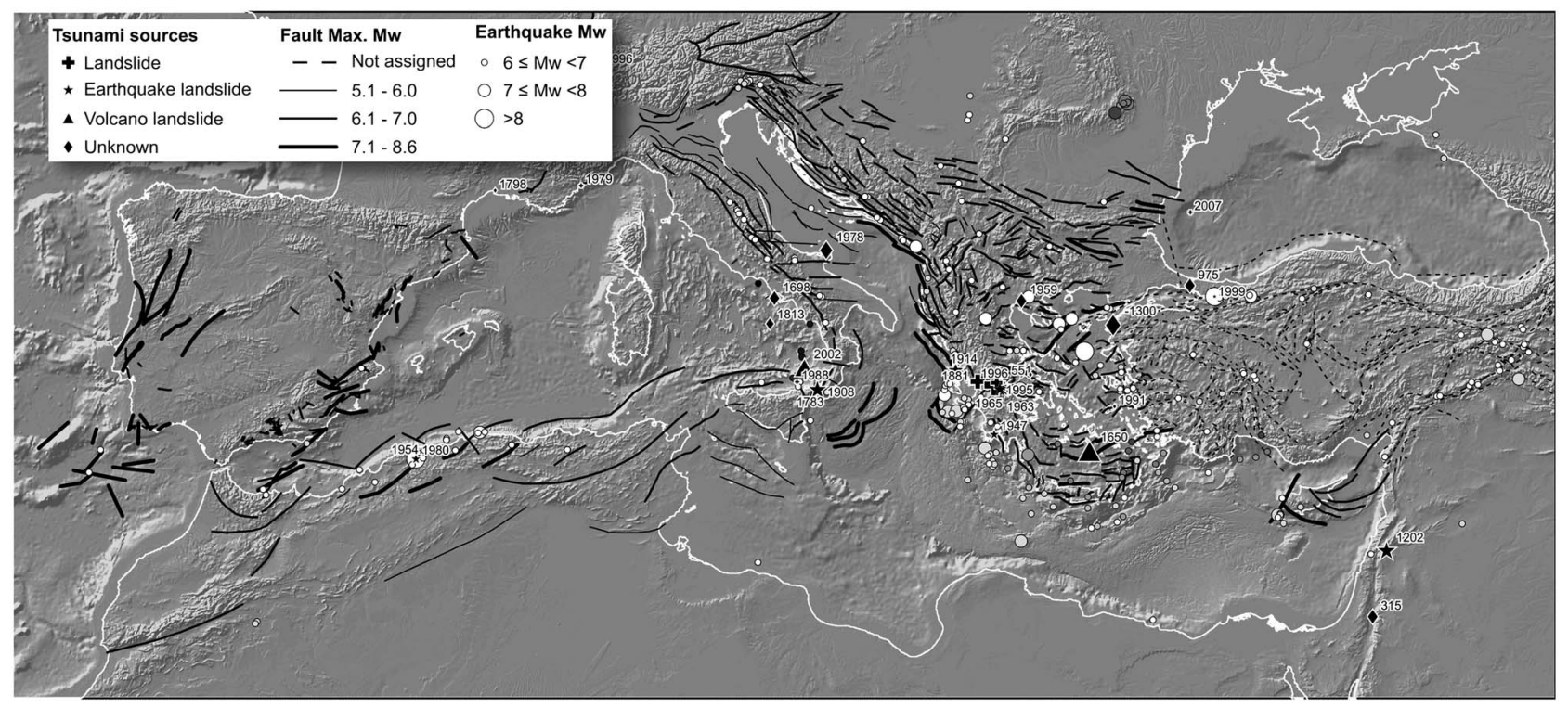

Figure 1. Map displaying seismology (USGS-NEIC http://earthquake.usgs.gov/regional/neic/; circles proportional to magnitude and darker colors representing deeper earthquakes) and seismogenic crustal faults (trace of the fault plane upper edge) [Basili et al., 2013]. Fault trace thickness is proportional to maximum magnitude $\left(M_{w}\right)$ value. Black symbols show location of landslide tsunami (National Geophysical Data Center/World Data Center Historical Tsunami Database, Boulder, CO, U.S., http://www.ngdc.noaa. gov/hazard/tsu_db.shtml; symbol size is proportional to tsunami magnitude; year of tsunami is shown in white outline font) on top of shaded relief [CIESM/Ifremer Medimap Group et al., 2008].

Brun, 2010], incipient continental collision [e.g., Royden, 1993], active [e.g., Meier et al., 2004] and passive margins [e.g., Roca et al., 1999], transcurrent margins [e.g., Schattner and Ben-Avraham, 2007], large river deltas (Nile, Rhone, Ebro, and Po), sediment-starved margins, and volcanic islands. Furthermore, the presence of a thick, widespread salt body in the relatively shallow subsurface (Messinain salt [e.g., Lofi et al., 2011]) has profound implications for fluid flow and tectonics of the continental margins.

[12] The Mediterranean region is also one of the world's most vulnerable areas to offshore geohazards, including submarine landslides. It is vulnerable because the Mediterranean Sea hosts a very high density of seafloor structures (e.g., oil platforms, offshore wind farms, cables, and pipelines) and its coasts are heavily populated. A study on behalf of the Submarine Cable Improvement Group showed that $25 \%$ of all damage caused to submarine cables in the Mediterranean Sea was due to natural hazards [Antony et al., 2008] including submarine landslides. Recent examples of cable breaks induced by submarine landslides on the Mediterranean margins include those offshore Algeria in 1954 and 1980 [El Robrini et al., 1985] and 2003 [Cattaneo et al., 2012] and the 1979 Nice airport landslide [Mulder et al., 1997]. In addition, some installations are potentially capable of releasing hydrocarbon pollutants into Mediterranean waters if damaged, which makes the Mediterranean a highly sensitive area environmentally.

[13] As stated above, the Mediterranean coastline is one of the most densely populated with 160 million inhabitants sharing $46,000 \mathrm{~km}$ of coastline (3.5 inhabitants per meter of coastline). In addition, the Mediterranean is the world's leading holiday destination, receiving up to $30 \%$ of global tourism and an average of 135 million visitors annually; this number is predicted to increase to $235-350$ million tourists by year 2025 [European Environmental Agency, 1999]. Yet, due to its relatively small size and the proximity of tsunami sources to impact areas, there is limited time for early warning to reach coastal populations.

[14] The Mediterranean Sea is peculiar in many respects, as it is, for instance, devoid of large tides and bottom water temperatures are warmer than in the global ocean $\left(\sim 13^{\circ} \mathrm{C}\right.$; e.g., Della Vedova et al. [2003]). The latter implies that the gas hydrate stability zone in marine sediments of the Mediterranean Sea is thinner than in any other ocean and gas hydrates are present only in a few localized spots [e.g., Woodside et al., 1998; Dondurur et al., 2012]. A wider presence of gas hydrates in sediments of the Mediterranean Sea has, however, been suspected during the last glacial maximum [Praeg et al., 2007].

[15] The historic record of natural disasters generated by submarine processes such as tsunamis and volcanic island eruptions is unusually rich in the Mediterranean. Some of the historic tsunamis are related to submarine landslides; e.g., destruction of the harbor of Herod the Great in A.D. 115 at Caesarea Maritima, Israel [Salamon et al., 2007], the 1783 Scilla coastal landslide in Italy [Mazzanti and Bozzano, 2011], the 1979 Nice airport landslide [Assier-Rzadkiewicz et al., 2000], the 1980 El-Asnam 7.3 $M_{s}$ earthquake and landslide [El Robrini et al., 1985], or the 2002 Stromboli volcano landslide [Chiocci et al., 2008]. In other instances, despite the lack of direct evidence, tsunami characteristics are difficult to reconcile with available seismological information suggesting slope failure phenomena are at the origin of tsunamis; e.g., the 1908 Messina, Italy [Billi et al., 2008] and 1956 central Aegean Sea tsunamis [Perissoratis and Papadopoulos, 1999]. The interaction between tsunamis 


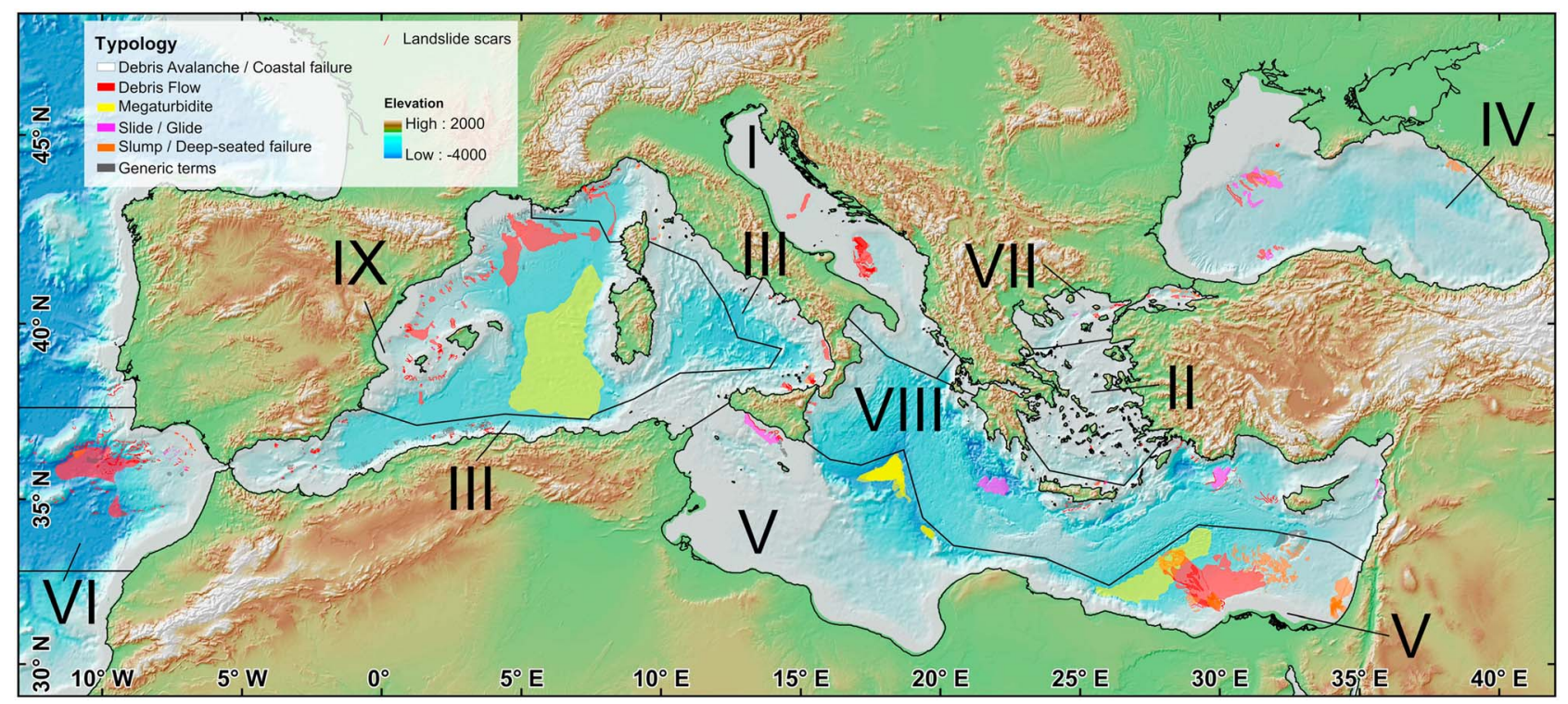

Figure 2. Map of landslide distribution in the Mediterranean Sea according to typology on top of bathymetric shaded relief [CIESM/Ifremer Medimap Group et al., 2008]. Landslide bodies are set transparent to identify overlapping deposits. Map shows zones for cumulative distributions in Figure 5.

and slope failure is sometimes rather complex as shown by the Değirmendere coastal landslide in Turkey, triggered during the 1999 Izmit earthquake [Tinti et al., 2006].

[16] With this study, we aim to provide an overview of the phenomenon of submarine slope failure at the scale of a large marine basin encompassing tectonically active and passive continental margins under variable sediment input. We attempt to do this by evaluating a large data set that, when treated statistically, sheds new light on the trigger mechanisms, dynamics, and frequency-magnitude distribution of submarine landslides. The main hypotheses we aim to test are that (1) the geological setting exerts a significant influence on submarine landslide activity (geohazard) and overall flux of sediment derived from such process and (2) climate and sea level fluctuations also exert a control on submarine landslide activity.

\section{Material and Methods}

[17] The data used in this manuscript are a compilation of information for 696 mass-transport deposits (MTDs) and 924 failure scars (Figure 2) combined with bathymetric information [CIESM/Ifremer Medimap Group et al., 2008] and tectonic [Basili et al., 2013] and seismologic data (U.S. Geological Survey-National Earthquake Information Center (USGS-NEIC), http://earthquake.usgs.gov/regional/ neic/). Despite the fact that some of the data included in the database come from unpublished data sets (particularly in the margins of eastern Iberia), more of these data are collected from the scientific literature (see Appendix I in the supporting information). For data extracted from the literature, we only used sources that included data presented in figure form that unequivocally imaged and mapped submarine landslide deposit(s) or failure scars. Data incorporation included capture or scanning of the map and image registration within ArcGIS 9.2 using available geographic data such as map coordinates and (less often) coastline elements. The failure scars and
MTDs were then digitized within ArcGIS, and the relevant information from the article was assigned to each element (MTD or failure scar). Our final database ultimately contains information on area, volume, thickness, typology, age, recurrence time (if any), geological setting (e.g., strike slip margin and passive margin), estimated or observed trigger mechanism, relationship to fluid escape structures, name of MTD (if any), height of the headwall where failure initiated, water depth at the top and bottom of the headwall, a binary field indicating whether or not the failure generated a tsunami (either observed or deduced from modeling results), a binary field indicating whether or not there is geotechnical information available in the surrounding area, and, finally, one or more reference articles and their DOIs (see Appendix I in the supporting information). Our analysis most often refers to the statistics derived from the failure deposits rather than the failure scarps, as more information could be derived from the first.

[18] It should be stressed that the information is neither uniform nor of the same quality throughout the set of articles used for input into the database. For instance, ages from radiocarbon dating might be reported in calibrated or noncalibrated years. In many occasions the age is, however, also reported with respect to the "marine isotope stages" and even more frequently is just reported with a geologic epoch. In this paper we do not attempt to compensate for the differences in dating methods, and ages/timing of failures reported in this paper should only be considered rough estimates.

[19] Submarine landslide classification information (e.g., in slides, slumps, or debris flows [Nardin et al., 1979; Mulder and Cochonat, 1996; Locat and Lee, 2002]) often provide some key indications on the failure dynamics that are useful in determining the failure consequences [e.g., Watts et al., 2003]. The typology used in this article most often honors the terminology used by the authors in the original manuscripts and includes the terms deep-seated failure (when recognized mainly in deep penetration seismic profiles 


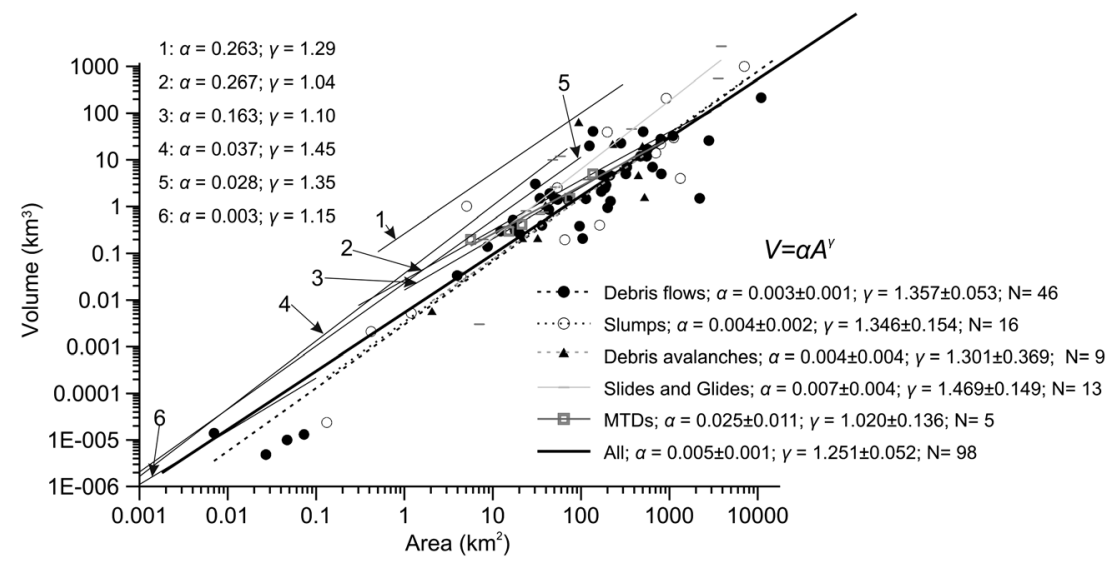

Figure 3. Area versus volume for different failure types. Relationships provided for other submarine environments such as offshore Puerto Rico (1) [ten Brink et al., 2006], the Storegga Slide (2) [Haflidason et al., 2005], and the U.S. Atlantic margin (3) [Chaytor et al., 2009] are also reported. Additionally, the relationship of Guzzetti et al. [2009] for terrestrial landslides of the slide type (4) and the relationships for subaerial failures in bedrock (5) and soil (6) reported by Larsen et al. [2010] are also plotted.

ratherthan bathymetric maps), slump, slide, glide, debris avalanche, debris flow, and megaturbidite. However, in the literature, MTDs are often classified with generic terms such as mass-transport deposit, mass-wasting deposit, gravitational collapse, or mass failure. In some instances, where slope failures were identified with these generic terms but the manuscript provided detailed morphology and subsurface data that allowed a more rigorous classification, we assigned a more specific term (i.e., slump, slide, or debris flow) to better characterize postfailure dynamics.

[20] Incorporation within a geographic information system (GIS) framework of the outline of the mass-transport deposits together with bathymetric data allowed us to calculate runout of the failed masses, area, volume (when not reported in the original article), minimum and maximum depth, minimum and maximum slope angle, and latitude and longitude of centroids. If volume was not reported in the original articles, we calculated the volume taking into account the typology of the landslide and scaling laws developed for each typology with available area and volume data (Figure 3). Minimum and maximum depth as well as minimum and maximum slope angle were obtained using ArcGIS Zonal Statistics over the bathymetric and slope-derived grids. Uncertainty of the volumes reported in the original articles (Appendix I in the supporting information) cannot be assessed in this paper. These volumes may be affected by inaccuracies in digitizing the boundaries of the failure mass or result from limited spatial information (i.e., when submarine landslides are imaged along only a few seismic lines). It is also not always easy to distinguish amalgamated events in seismic reflection data, which may induce a bias toward larger landslides. Volumes estimated in this work from landslide scaling laws can be subject to substantial error as a small difference in the exponent of the power law leads to substantial variance in volume predictions. Larsen et al. [2010] indicated that varying the exponent of the power law from 1.4 to 1.5 overestimates the predicted volumes by a factor of 2 . The areas from which these volumes were estimated may also suffer from imprecisions in digitizing landslide boundaries in the original articles and from georeferencing images from one projection system into that of our GIS project.
[21] Fitting power laws to the size (volume) distribution of submarine landslides in the Mediterranean Sea was accomplished following the method detailed in Clauset et al. [2009] using the R software [R Core Team, 2012] and the poweRlaw package [Gillespie, 2013]. For power fits of bivariate data (e.g., volume-area relationship in Figure 3), the empirical data were log transformed and a maximum likelihood (Tukey bisquare) robust linear fit [Venables and Ripley, 2002] was used to account for problems associated with outliers and the fitting of data spanning multiple orders of magnitude.

\section{Results}

\subsection{Spatial Distribution}

[22] Despite the recent progress in compiling a detailed image of the floor or the Mediterranean Sea beyond the shelf break [CIESM/Ifremer Medimap Group et al., 2008], large areas have not been surveyed to date by means of high-resolution geophysical tools such as swath bathymetry. Therefore, a striking feature of the database is that there is a noticeable correlation between known slope failure events and available high-resolution geophysical data. This correlation stresses that, despite recent advances, the catalog of submarine slope failures in the Mediterranean is still incomplete (especially for the North African margin) and further efforts need to be undertaken in order to address this situation.

[23] Published data (see Appendix I in the supporting information) suggest that submarine landslides occur in all geological settings of the Mediterranean continental margins. The database (Figure 2) shows two areas where the largest slope failures appear to concentrate: The Nile delta (region $\mathrm{V}$ ) and the Rhone-Ebro margins (region IX). These are not considered tectonically active areas based on instrumental seismicity [Vannucci et al., 2004]. Submarine landslides in areas that show instrumental seismic activity above $M_{w} 6$, such as the Algerian margin, also show submarine landslide activity, but their areal extent is much smaller (Figures 1 and 2). It is remarkable that the most tectonically active area (the Hellenic Arc) has a relatively low number of known slope failure events (Figures 1 and 2). Along the same line 

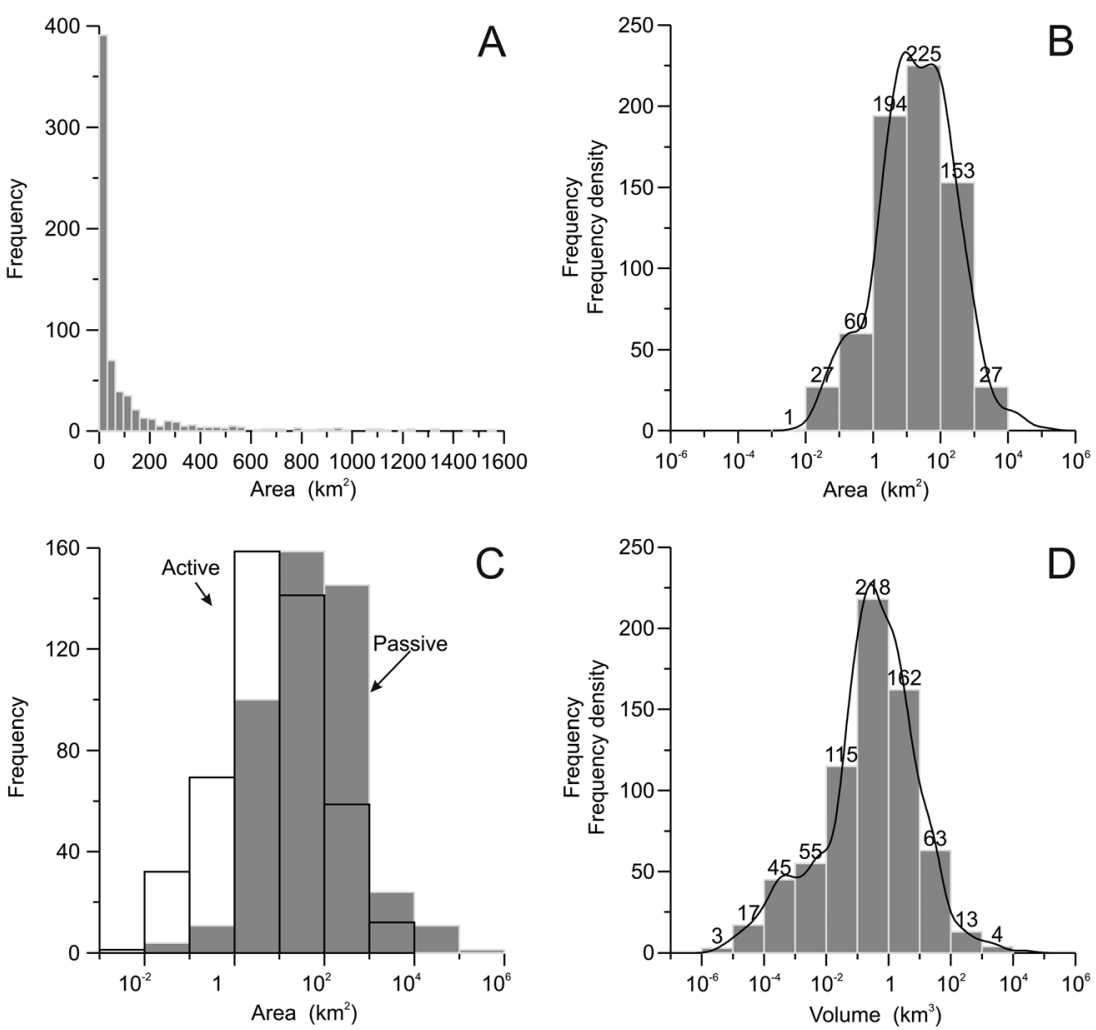

Figure 4. Magnitude indicators of submarine landslides in the Mediterranean Sea. (a) Area (linear scale) versus frequency, (b) area (log scale) versus frequency and kernel density function, (c) area (log scale) versus frequency for passive (grey) and active (white with black outline) margins (see Figure 1 for active tectonic structures in the Mediterranean Sea), (d) volume (log scale) versus frequency and kernel density function.

of reasoning, the deformation fronts of the Mediterranean and Calabrian ridges do not appear to host significant submarine landslides. This observation appears to be in remarkable contradiction with the fossil record, where the majority of mass-wasting deposits (including olistostromes) are associated with seismically active Mediterranean margins [Pini, 1999, Camerlenghi and Pini, 2009]. It also appears to be in contradiction with the common hypothesis that many submarine landslides have been ultimately triggered by earthquakes (cyclic loading driven by seismic shaking), as this phenomenon has been reported for most large historical submarine landslides [e.g., Hampton et al., 1996, Masson et al. 2006]. Therefore, the present distribution of submarine landslides in the Mediterranean Sea appears to support the existence in the literature (see Appendix I in the supporting information) of a paradigm of earthquakes as triggers of modern submarine landslides and a paradox concerning their distribution on present-day and ancient continental margins.

\subsection{Magnitude Characteristics: Area, Volume, and Failure Scars}

[24] Most of the submarine landslides in the database are in general of moderate magnitude, with areas that do not exceed $100 \mathrm{~km}^{2}$ and volumes below $50 \mathrm{~km}^{3}$ (Figure 4). Only in some extreme cases do the landslides affect areas and volumes that are similar to those of large landslides along Atlantic continental margins such as Storegga $\left(3500 \mathrm{~km}^{3}[\right.$ Bryn et al., 2003]), Traednajupet $\left(900 \mathrm{~km}^{3}\right.$ [Laberg and Vorren, 2000]), or the Canary $\left(400 \mathrm{~km}^{3}\right.$, [Masson, 1994]) submarine landslides. Some examples of extreme Mediterranean landslides are the Rosetta Slide Complex on the Nile Fan [Garziglia et al., 2008], the Early Pleistocene glides and debris flows in the Gela Basin [Trincardi and Argnani, 1990], and the Plio-Quaternary slumps of the Israeli slope [FreyMartínez et al., 2005]. Also, the enigmatic $22 \mathrm{kyr}$ old megaturbidite on the Balearic abyssal has a volume that exceeds $1000 \mathrm{~km}^{3}$ [Rothwell et al., 2000], and the Late Miocene (Tortonian) olistorstromal body at the foot of the Gulf of Cadiz has been shown to exceed $23,000 \mathrm{~km}^{3}$, though data suggest that these two deposits result from amalgamation of various events [Droz et al., 2006, Iribarren et al., 2007]. Seismic data suggest, however, that little time span occurred between subevents of these two major events [Droz et al., 2006, Iribarren et al., 2007] and therefore can be considered as part of one single landsliding event (and are treated as such within this manuscript). When volumes and areas are plotted on a log scale, it is evident that there is a characteristic size in Mediterranean landslides. Most of them range between 10 and $100 \mathrm{~km}^{2}$ and 0.1 and $1 \mathrm{~km}^{3}$ (modal classes; Figure 4). Separating landslide size according to a simplified tectonic classification of Mediterranean continental margins (i.e., binary active-non-active) shows that the modal size of submarine landslides on passive margins can be 1 to 2 orders of magnitude larger (modal classes are $1-10 \mathrm{~km}^{2}$ for active margins versus $10-100 \mathrm{~km}^{2}$ in passive margins; Figure 4c). Considering submarine landslides of Late Pleistocene and younger age, passive margins of the Nile and Ebro-Rhone rivers, together with the Adriatic Sea 
Table 1. Parameters for Landslide Volume-Cumulative Frequency Distributions in Figure $5 b^{a}$

\begin{tabular}{lcccccc}
\hline Region & Type & $a$ & $\theta$ & $p$ Value & $n$ & Interval \\
\hline I & $\mathrm{A}$ & 135.47 & 1.17 & 0.39 & 6 & $1.25-137$ \\
II & $\mathrm{A}$ & 0.41 & 0.60 & 0.94 & 18 & $0.0017-4.4$ \\
III & $\mathrm{A}$ & 37.93 & 0.63 & 0.99 & 132 & $0.14-46$ \\
IV & $\mathrm{P}$ & 40.71 & 0.55 & 0.26 & 26 & $2.24-737$ \\
V & $\mathrm{P}, \mathrm{S}$ & 102.35 & 0.54 & 0.96 & 77 & $1.70-4210$ \\
VI & $\mathrm{S}$ & 20.18 & 0.46 & 0.99 & 22 & $0.82-23000$ \\
VII & $\mathrm{A}$ & 5.74 & 0.99 & 0.10 & 8 & $0.71-4.6$ \\
VIII & $\mathrm{A}, \mathrm{S}$ & 21.88 & 0.51 & 0.45 & 15 & $2.11-2071$ \\
IX & $\mathrm{P}$ & 25.92 & 0.49 & 0.99 & 57 & $0.20-500$ \\
All & & 259.47 & 0.54 & 1.00 & 229 & $1.25-23000$
\end{tabular}

${ }^{\mathrm{a}}$ Region types have been broadly subdivided into A: active, P: passive, and S: strongly influenced by salt tectonics. See Figure 2 for key to regions. $a$ is the constant and $\theta$ the cumulative power law scaling exponent in the power law relating cumulative number of events $\left(N_{L}\right)$ versus volume $(V)$ distribution $\left(N_{L}=a V^{\theta}\right) ; p$ value is a goodness-of-fit test to quantify the plausibility that the power law provides a plausible fit to the data [Clauset et al., 2009]. If $p \simeq 0$, then the model does not provide a plausible fit to the data and another distribution may be more appropriate [Gillespie, 2013]; $n$ : sample size used in power law fitting; "Interval" refers to the power law fit range.

region, fed by the Po River, offer the highest sediment fluxes from submarine slope failure. The sediment fluxes (measured in cubic kilometers of sediment per kiloyear per square kilometer of continental margin with a slope greater than $1^{\circ}$ ) are, respectively, 30.83, 5.08, and $5.95 \times 10^{-5} \mathrm{~km}^{3} \mathrm{kyr}^{-1} \mathrm{~km}^{-2}$ for regions V, IX, and I (see Figure 2). The flux of sediment from submarine slope failures of Late Pleistocene and younger age for the active Algerian and Hellenic-Calabrian Arc regions is remarkably lower with values of 0.38 and $2.20 \times 10^{-5} \mathrm{~km}^{3}$ $\mathrm{kyr}^{-1} \mathrm{~km}^{-2}$ (regions III and VIII; see Table 1 and Figure 2).

\subsubsection{Volume}

[25] The frequency-volume (or area) distribution of landslide events quantifies the number of landslides that occur at different sizes [Malamud et al., 2004]. Recent studies have shown that landslide magnitude, in terms of both area and volume, exhibit power law scaling [Stark and Hovius, 2001; Malamud et al., 2004]. The number of observed landslides usually displays a negative power function of the landslide magnitude, across some magnitude range. Stark and Hovius [2001] indicate that this relationship holds true whether the landslide size is defined from the scar area or the total area disturbed and whether the landslides are triggered over a long period of time or almost instantaneously [see Stark and Hovius, 2001, and references therein]. Difficulty in accessing the marine environment has resulted in few submarine landslide magnitude distributions being investigated [Issler et al., 2005; ten Brink et al., 2006, Micallef et al., 2008; Chaytor et al., 2009; Moernaut and De Batist, 2011]. These distributions have been reported to conform to power law [ten Brink et al., 2006; Micallef et al., 2008], logarithmic [Issler et al., 2005] or lognormal [Chaytor et al., 2009; ten Brink et al., 2009]. We find that the volume of submarine landslides in the Mediterranean Sea fit to a power law behavior (Figure 5; $N_{L}=259 V_{L}^{-0.54}$ ), over the largest 4 orders of magnitude $\left(1-1000 \mathrm{~km}^{3}\right)$. Attempting to fit a power law distribution to the whole submarine landslide inventory yields relatively poor results. Both the lognormal and power law distributions can only be fit to a subset of the data (Figure 5). To compare the two fits, a standard technique is to use Vuong's test [Vuong, 1989], which is a likelihood ratio test for model
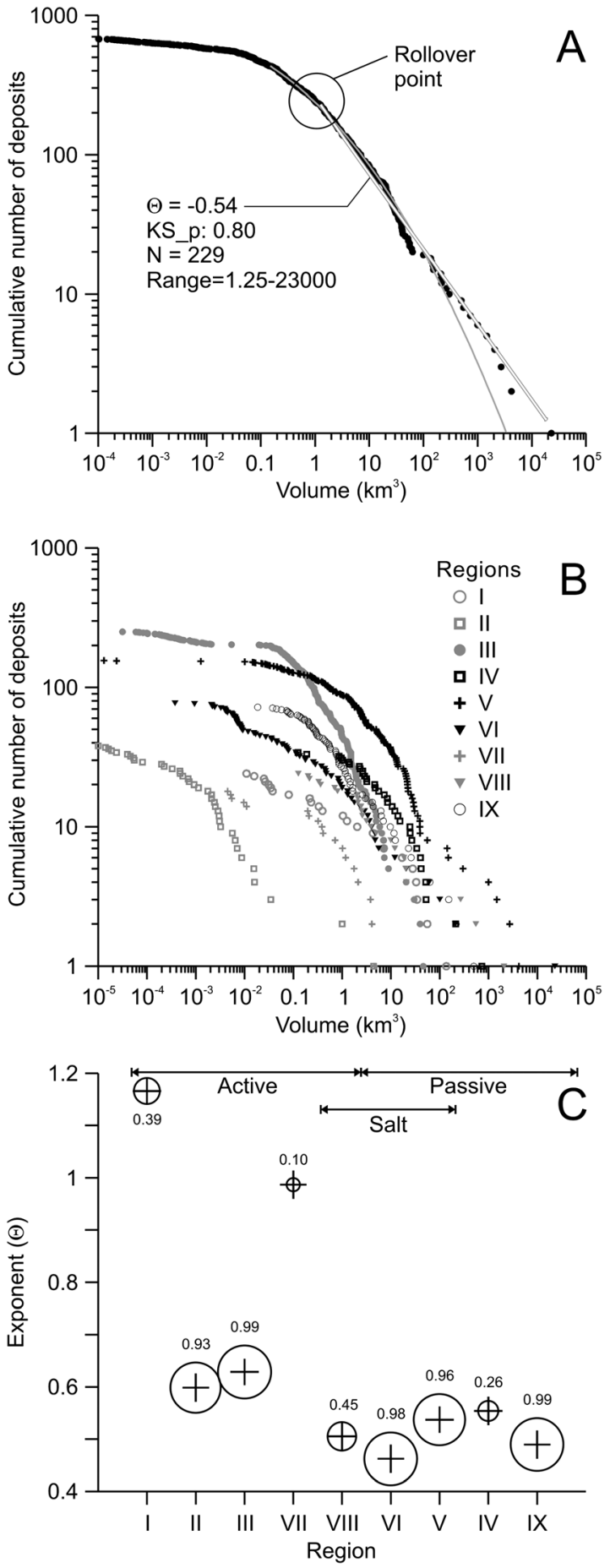

Figure 5. (a) Cumulative-volume distribution of 696 landslide deposits. Thick grey line with white center shows power fit for landslides $1.25-23,000 \mathrm{~km}^{3}$, while grey line shows lognormal fit for the $0.15-23,000 \mathrm{~km}^{3}$ portion of the landslide inventory. (b) Cumulative-volume distribution of the 696 observed landslide deposits separated by region (see Figure 2). Those occurring in passive margins are shown with black dots and those in active margins with grey dots. (c) Exponent of the power laws in Figure 5b sorted by region type. Circle size shows the $p$ value goodness-of-fit estimator (labeled). Note that exponents of power laws in active regions appear higher, despite those with the highest values are the ones with the lowest $p$ values (see also Table 1). 


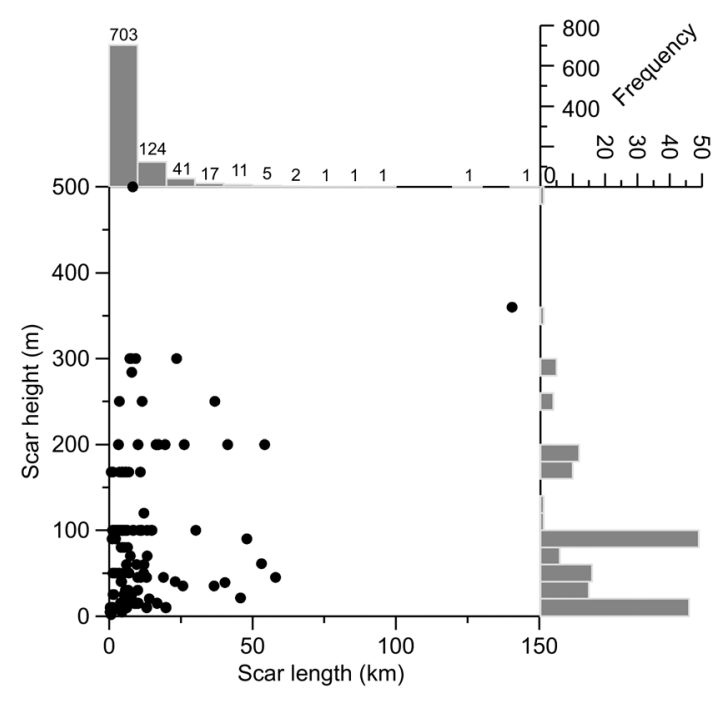

Figure 6. Scar length to scar height relationship. Note that scar length can be directly computed for all digitized failure scars, but scar height is not available for all of them.

selection. The test statistic, the ratio of the log likelihoods of the data between the two competing models, yields a value of -0.675 , which suggests that one model cannot be favored over the other. The lognormal distribution fits landslides with volumes 1 order of magnitude lower, but the fit for the largest 2 orders of magnitude landslides is poorer.

[26] As various authors have pointed out [Stark and Hovius, 2001; Guzzetti et al., 2002; Malamud et al., 2004; Chaytor et al., 2009; Stark and Guzzetti, 2009], power law fit for truncated portions of data may likely reflect observational limitations, but it may also be due to a more fundamental characteristic of the area, such as geologic control on the landslides, or it may be related to a dynamic feature of the landslide processes that controls their size. In the marine environment, there is a clear limitation imposed by the resolution of multibeam systems. However, because the data set in this work is constructed from shallow and deep water systems, the limitation should not affect the distribution to the same extent such as that reported in Chaytor et al. [2009]. Furthermore, because of the depositional nature of the marine environment, most morphologies tend to be draped and preserved and landslides that are several hundred thousand or even million years old are commonly observed on the seafloor [Lastras et al., 2007]. The exponent $(\theta)$ of the power law equation for landslides in the Mediterranean Sea is 0.54 with a standard deviation of 0.053 (Figure 5). This exponent is between those reported for the U.S. Atlantic Continental Margin (1.3) [Chaytor et al., 2009] and the value of 0.44 reported for the series of subevents related to the Storegga Slide [ten Brink et al., 2006; from data in Haflidason et al., 2005]. Such a relationship implies that there are 3.5 times more landslides of $1 \mathrm{~km}^{3}$ than landslides of $10 \mathrm{~km}^{3}$ and $\sim 12$ times $\left(3.5^{2}\right)$ more landslides than landslides of $100 \mathrm{~km}^{3}$ and so on. A sensitivity analysis shows that variation in the exponent of the frequency-magnitude relationship $(\theta)$ related to uncertainties in volume estimation from the power-scaling relationships in Figure 3 for landslides which volume was not reported in the original papers is rather low. Varying the scaling exponent of the volume to area $(V / A)$ relationship between 1.1 and 1.5 results in variations of the frequencymagnitude scaling exponent $(\theta)$ of \pm 0.04 .

[27] Assuming that the truncated behavior of the power law relationship results from observational limitations and that the cumulative-volume data conform to a Pareto distribution implies that the median landslide size in the Mediterranean Sea is $0.14 \mathrm{~km}^{3}$ (the median size from the volumes recorded in the database is $0.31 \mathrm{~km}^{3}$ ). The fact that the exponent of the power law equation (Figure $5 \mathrm{a}$ ) is less than 1 indicates that the few largest failure volumes dominate the failure processes. In this regard, if we look only at landslides of Quaternary age, the largest 51 landslides out of 471 Quaternary landslides in the database (i.e., $\sim 10 \%$ of the Quaternary population) represent $95 \%$ of the total volume involved in the landslide process.

[28] Separating the landslides in different regions, according to tectonic setting (Figures $5 \mathrm{~b}$ and $5 \mathrm{c}$ and Table 1 ), reveals that different trends exist in the scaling behavior of landslides, something that can also be seen in the mapped distribution shown in Figure 2. It appears that the exponent $(\theta)$ of the power law is between 0.46 and 0.55 for landslide distributions in passive margins and between 0.51 and 1.17 in active margins, despite that the areas displaying the highest exponent are also those displaying the lowest goodness-of-fit $p$ value (Figure 5c and Table 1). Active tectonic areas where significant Messinian salt accumulations occur display the lowest values of $\theta$, probably induced by the presence of relatively large slope failures related to salt flow and diapirism.

\subsubsection{Area}

[29] A power law fit of the area of the landslide deposits versus cumulative number shows an exponent of 0.80 $\left(N_{L}=9399 A_{L}^{-0.80}\right)$ and a median landslide size of $19.1 \mathrm{~km}^{2}$. The power law fits submarine landslides with areas in the range of 230 to $131,220 \mathrm{~km}^{2}$ (i.e., the largest 4 orders of magnitude), but in this case the lognormal distribution offers a better fit over the 0.12 to $7064.2 \mathrm{~km}^{2}$ range, spanning 5 orders of magnitude, with a mean and standard deviation on the $\log$ scale of 3.07 and $2.52 \mathrm{~km}^{2}$. The surface expression of all deposits resulting from mass wasting in the Mediterranean Sea occupies $18 \%$ of its seafloor, therefore highlighting that landslide processes are an important sediment remobilization and transport mechanism offshore. This percentage can be compared with other passive margins such as the Gulf of Mexico with $\sim 27 \%$ or the New Jersey Margin with $\sim 9.5 \%$ [McAdoo et al., 2000]. The tectonically active margins of California with $\sim 7 \%$ and Oregon with $\sim 3 \%$ [McAdoo et al., 2000] present a significantly lower proportion. The volcanically dominated slopes around the Canary Islands present intermediate values with $\sim 10 \%$ of its seafloor occupied by sediment gravity flows [Urgeles et al., 2001].

\subsubsection{Headwall Scars}

[30] Headwall scars of submarine landslides in the Mediterranean Sea may disrupt significant portions of seafloor and extend for distances larger than $100 \mathrm{~km}$. However, about $75 \%$ of all failure scars have lengths not exceeding $10 \mathrm{~km}$ (Figure 6). The scars may also have considerable elevation and may often disrupt sedimentary packages up to $100 \mathrm{~m}$ thick. Some larger events may even cut into sedimentary sequences of $150-300 \mathrm{~m}$ and even reach $500 \mathrm{~m}$ deep (Figure 6). Contrary to previous studies onland [Hovius et al., 1997], we find that the length of the failure scar and the maximum depth of incision along that failure scar show no obvious relationship. Failure scars are found in all water 

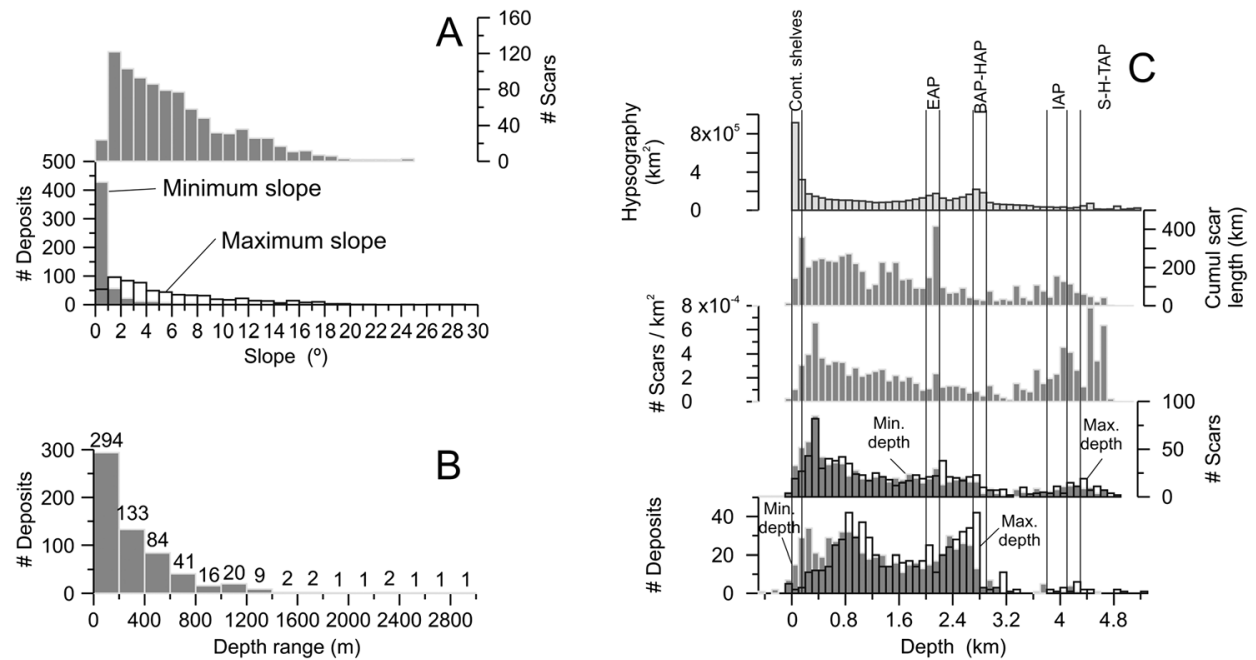

Figure 7. (a) Maximum angle along landslide scars (top) and minimum and maximum slope angle along landslide deposits (bottom). (b) Vertical displacement for submarine landslide deposits. (c) Depth distribution of submarine landslides; (top to bottom) Mediterranean Sea (+ Black sea and Gulf of Cadiz) hypsography, cumulative scar length per depth interval, number of scars per unit area of seafloor, minimum and maximum depth of scars, and minimum and maximum depth of deposits; labels for most relevant features controlling the hypsometry of the Mediterranean and adjacent seas are shown (EAP: Euxine Abyssal Plain; BAP-HAP: Balearic Abyssal Plain-Herodotus Abyssal Plain; IAP: Ionian Abyssal Plain; S-H-TAP: Seine-Horseshoe-Tagus Abyssal Plains). When two values (e.g., minimum and maximum along the landslide deposit) are plotted together, grey-filled bars indicate always the minimum value, and open, black outline bars indicate the maximum value.

depths in the Mediterranean Sea but particularly above $2800 \mathrm{~m}$, and remarkably $\sim$ one third of all failure scars are found between 200 and $600 \mathrm{~m}$ water depth on the continental slope (Figure 7a). The longest failure scars are, however, found in relatively deep waters, some of them associated with salt tectonics [e.g., Woodside et al., 1998; Zitter et al., 2003]. The deeper areas, mainly in the Gulf of Cadiz (Region VI; Table 1), have an unusually high proportion of submarine slope failure scars (Figure 7c).

\subsection{Dynamic Characteristics: Typology, Runout, Vertical Displacement, and Slope Gradients}

[31] Various classifications of submarine landslides have been proposed [Nardin et al., 1979, Mulder and Cochonat,
1996; Mulder and Alexander, 2001; Locat and Lee, 2002]. Most of these classifications are based on the subaerial classification of landslides by Varnes [1978]. As these classifications are based on the sediment transport mechanisms, ascribing one particular failure to one type or another offers important insights into the mode of emplacement of the observed MTDs and on the postfailure dynamic characteristics of the landslide (including early acceleration and velocity history). In the scientific literature that we analyzed (Appendix I in the supporting information), we found that the data presented often allowed the classification of submarine slope failure processes into a specific type (e.g., slump, slide, or debris flow). However, in some cases generic terms such as MTD, mass failure, or mass wasting, which have no implications in
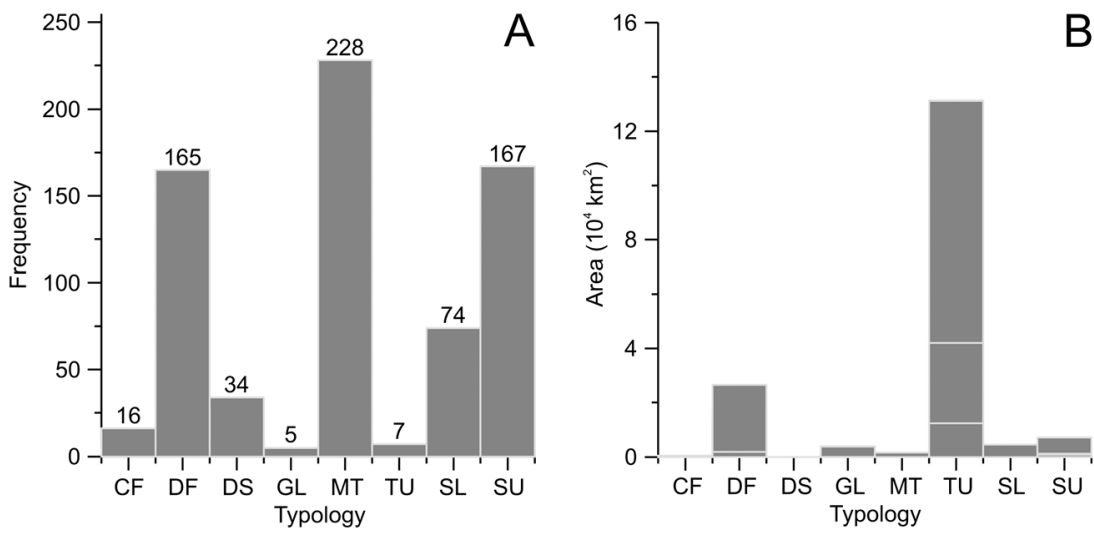

Figure 8. (a) Typology frequency, (b) typology versus area. CF: coastal failure, DF: debris flow, DS: deep-seated failure, GL: glide, MT: mass-transport deposit and other generic terms, TU: megaturbidite, SL: slide, SU: slump. 


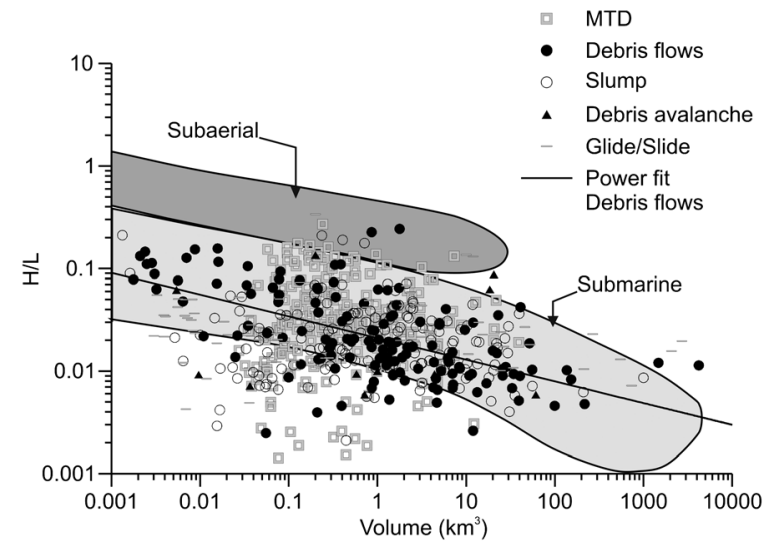

Figure 9. Height to runout $(H / L)$ ratio versus volume for different landslide types. The fields for submarine and subaerial landslides as indicated by Hampton et al. [1996], Locat [2001], Locat and Lee [2002], and De Blasio et al. [2006] are shown with grey polygons. The black line shows a power fit to debris flows' data (slope $=-0.22 \pm 0.02$ ). Subaerial landslides exclude landslides in quick clays.

terms of dynamic behavior of the failed masses, were used instead (Figure 8).

[32] Landslides that have been identified as slides or glides show steeper slopes of the $V / A$ relationship compared to other failure types such as debris flows and debris avalanches (Figure 3). This lower gradient likely reflects the disintegrative behavior of debris flows and debris avalanches, spreading over larger areas and commonly traveling longer distances with respect to slides and glides. However, slumps, a rather nondisintegrative failure type, also show a relatively low scaling exponent. The number of failures used for developing the scaling exponents is relatively small for some failure types and should be increased for a better characterization of the $V / A$ relationship.

[33] Differences in the exponent of the $V / A$ relationship have also been reported for subaerial landslides occurring in bedrock or soil [Hergarten, 2003; Larsen et al., 2010] and therefore likely with failure type too. Overall, we find slightly higher values of the $V / A$ scaling exponent (1.25) than those reported in the U.S. Atlantic margin (1.099 [Chaytor et al., 2009]) or the Storegga slide (1.032 [Haflidason et al., 2005]), and similar to those found off Puerto Rico (1.292 [ten Brink et al., 2006]). The scaling exponent found in this study for failures of the slide type (1.46) is close to the value obtained by Guzzetti et al. [2009] (1.45) for the same failure type. The scaling exponents for the other failure types are between those reported by Larsen et al. [2010] for subaerial failures in bedrock and soil.

[34] In most submarine landslides of the Mediterranean Sea, it is commonly observed that slope failures do not completely evacuate the failure area, and therefore the total length of the landslide deposit offers a reasonable estimate of runout distance and elevation drop of the failed mass. Figure 9 displays the position of subaerial and subaqueous landslides as reported by Hampton et al. [1996], Locat and Lee [2002], and DeBlasio et al. [2006] and that of submarine landslides in the Mediterranean Sea on the plane Log $(H / R)-\log (V)$. In Figure 9, $H$ is the fall height, $R$ is the runout, and $V$ is the volume. As Locat and Lee [2002] already showed for submarine landslides along other continental margins, the $H / R$ ratio of submarine landslides in the Mediterranean Sea for failures of similar volume is an order of magnitude lower than their subaerial counterparts (Figure 9). This fact points to a much lower apparent friction coefficient, which has been interpreted to result from hydroplaning [Mohrig et al., 1998; De Blasio et al., 2006]. All types of submarine slope failures in the Mediterranean Sea appear to have lower $H / R$ ratio than subaerial landslides and cluster in a similar fashion than submarine landslides reported in other continental margins [Hampton et al., 1996; Locat, 2001; Locat and Lee, 2002; De Blasio et al., 2006] (Figure 9). Such clustering includes some failure types that are unlikely to develop hydroplaning such as slumps (Figure 9), indicating that other factors such as sustained high pore pressures may play a significant role in runout development. Debris flows, however, is the only failure type displaying a somewhat consistent decrease in $H / L$ ratio with increasing volume, potentially highlighting the effect of hydroplaning.

[35] More than $50 \%$ of all landslides in the Mediterranean Sea originate on the continental slope (Figure 6), but a large number of events appear to deposit beyond the continental slope, indicating that the continental rise is often the place for accumulation of submarine slope failures. Also, most landslide deposits initiate in slopes $<5^{\circ}$ (Figure 7), which comes as no surprise, as failures, particularly those that develop on open slopes, often the largest ones, are limited by the gradient of the continental slope. Indeed, the modal class for the maximum slopes, both within landslide deposits and failure scars, is for slopes between 1 and $2^{\circ}$ (Figure 7). A possible explanation for such low gradients near the initiation area is that those slopes are rather characterized by sediment deposition and overpressure development, while above this angle the predominant process is sediment bypass. Another possible explanation is that margin stratigraphic architecture induces flow focusing at the foot of the slope, which results in higher excess pore pressure compared to that expected from the sedimentation rates and compressibility/permeability characteristics of continental rise sediments (see Dugan and Flemings [2000], Stigall and Dugan [2010], and Urgeles [2012] for further details). Most of the landslides arrest on very gentle slopes of $<1^{\circ}$ (Figure 7), which is in agreement with the low apparent friction coefficient (Figure 9) and the observed long runout.

\subsection{Timing of Failure and Recurrence Rates}

[36] Dating of submarine landslides is a difficult task that is rarely performed in great detail. The database currently holds 696 instances of mass-transport deposition, of which only 483 contain some age constraints and only 70 have been dated using relatively accurate techniques. In addition, there is a wide range in these more accurate dating techniques used in the literature, resulting in quite variable accuracies of landslide ages. These dating techniques span from purely biostratigraphic age estimates, including those that base dating on correlation from nearby cores and wells, or estimates based on broad, linear sedimentation rates to estimates derived from radiometric techniques including correlation to oxygen isotope records and radiocarbon dates reported in calibrated or uncalibrated years. Age resolution within the database may range from some million years to a few hundred years. Figure 10 shows that landslides for which relatively accurate dates exist have mostly occurred since the last sea level 


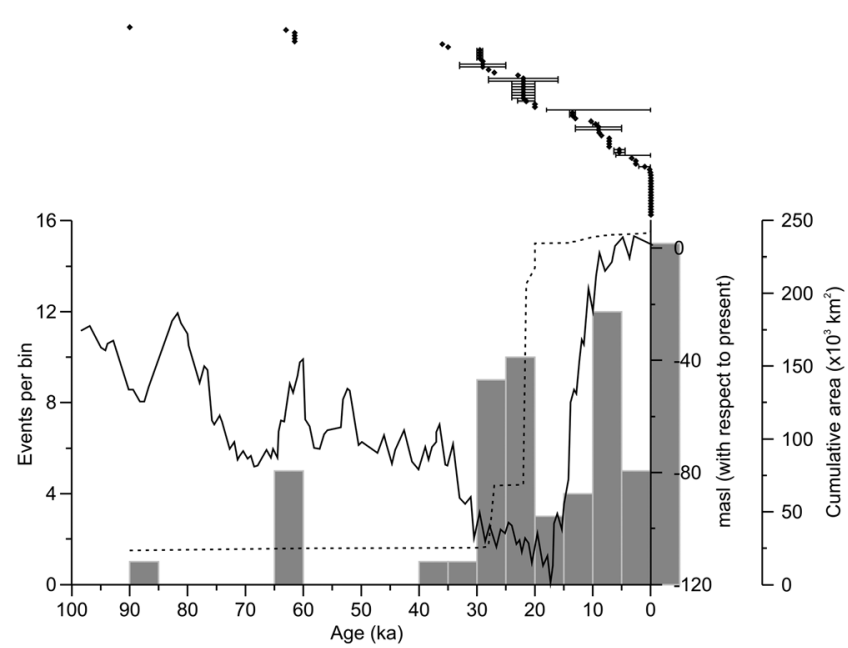

Figure 10. Number of submarine landslide events binned at $5 \mathrm{kyr}$ intervals with respect to age for the last $100 \mathrm{ka}$ (grey bars) plotted together with cumulative landslide area (dashed black line). Bins are constructed from mean ages. Also plotted for reference is the sea level curve from Pillans et al., 1998 (solid black line). Top plot shows individual landslide ages with available uncertainty information.

lowstand, while few failures older than $30 \mathrm{ka}$ have actually been mapped and dated. The cumulative area involved in those failures versus timing indicates that for the last $30 \mathrm{ka}$ most of the sediment flux from slope failure occurred during the last sea level lowstand (Figure 10) when the Mediterranean Sea was $\sim 120 \mathrm{~m}$ lower than it is at present. The plot is dominated by one dubious (in terms of multiphase character) extremely large event, the Balearic Abyssal Plain megaturbidite, but removing this event from the plot would result in a similar trend.

[37] For landslides that have just been loosely dated with an age epoch, 289 landslides (42\%) have been attributed a Late Pleistocene to Holocene age. Of those, 140 landslides have been dated as Holocene. Considering the time span of the Holocene $(\sim 12 \mathrm{ka})$, the apparent rate of landslide activity is higher in the Holocene. It therefore seems clear that there is a bias toward younger landslides in the database, and the problem is therefore how to analyze the temporal distribution of these submarine landslides. Geist et al. [2013] use several statistical techniques and probability models in addition to the Poisson model that include clustering and quasiperiodic behavior. They apply these techniques and models to a series of Late Pleistocene to Holocene MTDs recorded in two drill sites in the Ursa Basin, Gulf of Mexico, which are dated using biostratigraphy and magnetostratigraphy [Urgeles et al., 2007]. Geist et al. [2013] find that the deposits of these slope failures can be described by a Poisson process, although some model results show quasiperiodicity at one of the sites.

[38] Other authors have analyzed the timing and relationship of submarine landslides to climate and sea level changes using inventories of worldwide dated submarine landslides containing $<100$ large $\left(>1 \mathrm{~km}^{3}\right)$ events [Korup et al., 2012; Urlaub et al., 2013]. Korup et al. [2012] suggest a distinct clustering of submarine and subaerial landslides $>5 \mathrm{~km}^{3}$ at $10-15 \mathrm{ka}$ but propose that such change may be explained with the transition from statistical noise to a steady state representation of mobilization rates by landslides in the sedimentary archive. Urlaub et al. [2013] find no statistical evidence for a climate control on the timing of submarine landslides $>1 \mathrm{~km}^{3}$ and show that the observed distribution fits that of a Poisson process in which events are essentially random.

[39] Because of the pattern in the number of landslides in Figure 10 not being conclusive, the large uncertainty in recurrence rates derived from the few reliable dates available, inaccuracies in the dating methods, and results from previous studies reported in the previous paragraph, we will assume that the temporal distribution (at least during the Holocene) of submarine landslides in our database is that of a Poisson process. However, there are additional difficulties when deriving recurrence rates for landslides that have been dated with an epoch or period. Particularly, for the purpose of this study it should be noted that a landslide that has been dated as Quaternary could actually be Holocene because the Quaternary period includes the Holocene epoch.
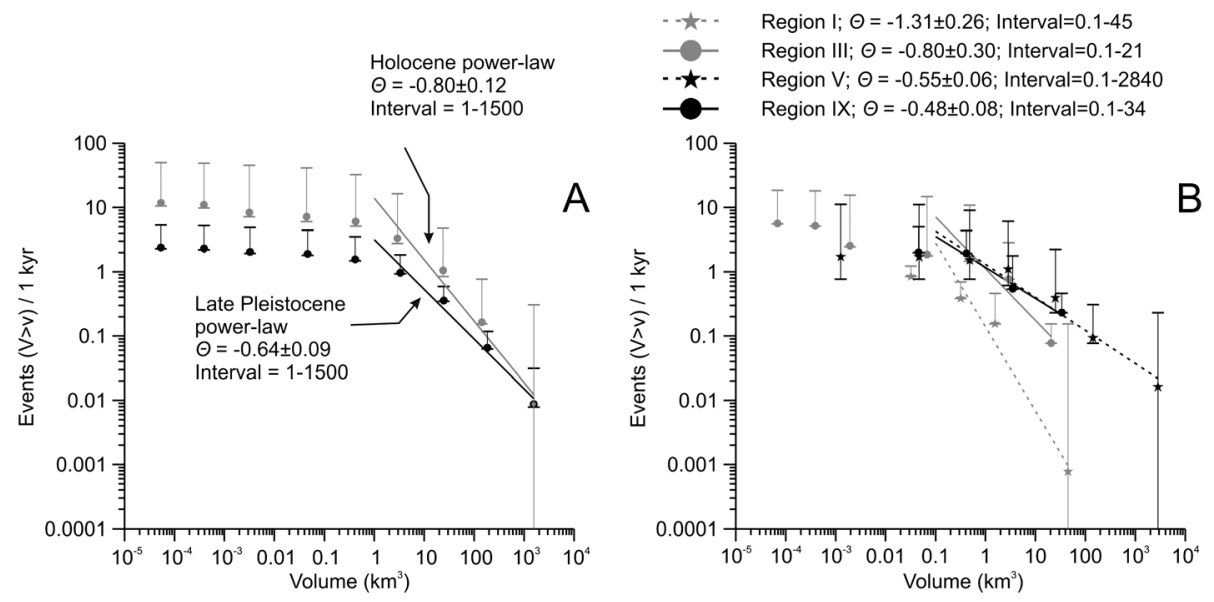

Figure 11. (a) Landsliding rates of the Mediterranean basin for the Holocene and Late Pleistocene $(<126$ kyr) periods showing power law behavior for the four largest orders of magnitude. (b) Landsliding rates with tentative power law fit for four regions (Figure 2) of the Mediterranean Sea during the Holocene. Grey and black symbols denote tectonically active and passive regions, respectively. Note steeper gradients of the power law for tectonically active regions compared to passive regions. 


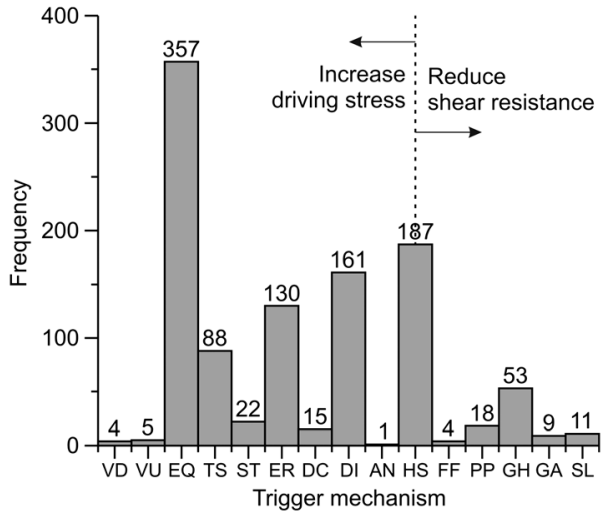

Figure 12. Major factors cited to be involved in triggering slope failure offshore (separated according to those that increase the driving stress and those that reduce the shear strength; VD: volcano development, VU: volcano uplift, EQ: earthquake, TS: tectonic steepening, ST: steepening, ER: erosion, DC: differential compaction, DI: diapirism, AN: anthropic, HS: high sedimentation rates, FF: fluid flow, PP: pore pressure, GH: gas hydrates, GA: gas, SL: sea level).

[40] Assuming such Poisson distribution, recurrence rates for this study have been calculated as landsliding rates (LR) according to

$$
\mathrm{LR}=N(V>v) / \Delta \mathrm{T}
$$

where $N(V>v)$ is the number of landslide events of volume $(V)$ larger than a given volume $(v)$, and $\Delta T$ is the time interval considered from present day. The recurrence rate is therefore $\mathrm{LR}^{-1}$. To account for the uncertainty that some landslides could actually occur within $\Delta T$ when the age of the landslides is reported with an age period that is larger than $\Delta T$, each individual event within $N(V>v)$ was weighed with a factor $\left(\Delta T-T e_{f}\right) / T e_{i}$ where $T e_{f}$ and $T e_{i}$ are the final and initial time within the landslide age interval. The upper and lower bounds to the uncertainty interval are provided by the $N(V>v)$ where $T e_{i}$ is lower than $\Delta T$ and the $N(V>v)$ where $T e_{f}$ is greater than $\Delta T$, respectively (Figure 11). As an example, for the Holocene ( $\Delta T=11 \mathrm{ka})$ relationship a landslide that has been dated as $5 \pm 0.5 \mathrm{ka}$ old will contribute one event to $N(V>v)$, while a landslide that has been dated as "Late Pleistocene to Holocene" will have a $T e_{f}$ and a $T e_{i}$ of $0 \mathrm{ka}$ and $126 \mathrm{ka}$ and will be weighted with a factor of 0.095 , thus contributing little to the mean $N(V>v)$. The uncertainty range in Figure 11 represents the minimum and maximum possible $N(V>v)$. For the top value of the uncertainty range the example above will contribute one event and not contribute at all for the bottom value. Only landslides with age uncertainty intervals that are completely within the age period being considered (the Holocene in this example) contribute one event to the minimum $N(V>v)$.

[41] Rates of submarine slope failure for the whole of the Mediterranean basin were computed for the Holocene $(0-12 \mathrm{ka})$ and Late Pleistocene to Present (0-126 ka) periods. The largest 3-4 orders of magnitude (volume) follow an inverse power law relationship (Figure 11a), with slopes of 0.80 for the last $12 \mathrm{kyr}$ and 0.64 for the last $126 \mathrm{kyr}$. Considering longer time periods reduces the overall rates of landslide activity and makes the slope of the power law gentler, therefore indicating the lack of smaller events as we go back in time and, probably, the addition of some old and extreme events. Therefore, the Holocene relationship probably provides the most accurate picture in terms of landslide activity of the basin. The landslide rates are higher for the Holocene period despite the total number of landslides in this period being lower. According to available data and extrapolating the power law curve in the area where the record appears incomplete, one could expect to have $\sim 1.5$ slope failures greater than $10^{-3} \mathrm{~km}^{3}$ every year in the Mediterranean Sea and only one slope failure in excess of $10 \mathrm{~km}^{3}$ every $\sim 1000$ years. Exceptional slope failures exceeding $10^{3} \mathrm{~km}^{3}$ may only be expected at recurrence rates close to $40 \mathrm{kyr}$ (Figure 11a). These values should be regarded as minimum estimates, as adding additional failures or having additional dates for the failures already present in the database is only likely to increase the overall LR. The large uncertainties in these data, particularly for the upper bound of the uncertainty interval, result from considering the possibility that the landslides that have been dated with a longer period (e.g., Quaternary) are actually Holocene or Late Pleistocene. For the largest magnitude landslides this effect is exacerbated by the fact that there are no Holocene but just Quaternary landslides of that magnitude range (Figure 11a); hence, results should be taken with caution.

[42] Subdividing the data set into different regions (at least for those where the number of landslides with age constraints allows for such analysis) shows that during the Holocene the slope of the power law is steeper for the regions displaying higher seismic activity, such as regions I and III (Figure 11b) in agreement with the frequency-magnitude relationships reported in Figure 5 and Table 1. For landslides $>0.1 \mathrm{~km}^{3}$ in size the recurrence rates are $\sim 150$ years in Region III and 180 in Region V. However, according to Figure 11b, Region $\mathrm{V}$, a passive margin, may double the number of landslides of magnitude $>10 \mathrm{~km}^{3}$ compared to Region III within the same time interval.

[43] It should be noted too, that in many instances it is observed that a particular landslide tends to recur at a particular location (e.g., the Ana Slide on the Balearic slope [Berndt et al., 2012]; the Big'95 on the Ebro Margin [Lastras et al., 2004]; and the Rosetta Slide on the Nile Fan [Garziglia et al., 2008]). Within the database, 63 events are reported to occur in areas were slope instability is a recurrent phenomenon. Examples of recurrence rates for this type of landslides are very limited because often borehole information is necessary. A few relevant examples from other areas are the Storegga slide [Haflidason et al. 2005] and recent results from the Ursa Basin [Geist et al., 2013] and Nankai Trough Seismogenic Zone Experiment [Strasser et al., 2012].

\subsection{Trigger Mechanisms and Relationship to Fluid Flow Features}

[44] The factors that are reported to induce slope failure in the Mediterranean Sea are diverse, and in some instances the combination of two, three, and even four factors are cited. Amongst the various factors, those that are most commonly reported are related to an increase in shear stress acting on the slope. Earthquakes are particularly highly cited as initiators of submarine slope failures with 341 instances. Diapirism, erosion, and tectonic steepening are also processes that produce an increase in shear stress and that are often cited as a major 
factor in triggering slope failures in the Mediterranean Sea (Figure 12). Despite the thick Messinian evaporite sequence in the Mediterranean Sea, diapirism is cited as a cause of slope failure mostly in the Gulf of Cadiz (Region VI) and the Nile Fan (V), and it is probably an important factor along the Mediterranean Ridge (VIII). This apparent lack of relationship in the remaining regions of the Mediterranean Sea is probably due to the fact that Messinian evaporites in the Mediterranean Basin are located in the basin floors, where slopes are close to 0 , while diapirism in the Gulf of Cadiz affects the accretionary prism on the continental slope [Gràcia et al., 2003]. The mechanisms that act to reduce the sediment shear strength are not described as often as those that act to increase the shear stress. Amongst those, high sedimentation rates is commonly stated as one of the major preconditions driving slope failure. Nonequilibrium consolidation due to high sedimentation rates of fine, low-permeability sediments is an efficient mechanism for pore pressure buildup [Urgeles, 2012]. Despite this evidence, pore pressure is cited only 18 times as a factor controlling slope failure initiation. Gas hydrates (mostly in the Gulf of Cadiz) and free gas have also been related to slope failure of the continental slope. Common presence of pockmarks (108 landslides in the database associate with this feature), mud volcanoes, free gas, and gas hydrates suggests that fluid flow is a major factor controlling initiation of slope failure [e.g., Woodside et al., 1998; Lastras et al., 2004; Garziglia et al., 2008]. Surprisingly, few papers have associated the presence of gas in marine sediments and pore pressure buildup from gas expansion during descending sea level [e.g., Lafuerza et al., 2012] as a major driver of slope instability.

\section{Discussion}

\subsection{Completeness of the Database}

[45] Malamud et al. [2004] classified landslide inventories into two classes: (1) landslide-event inventories that are associated with a particular trigger and (2) historical landslide inventories, which are the sum of one or many landslide events over time in a region. The inventory used in this study falls in this second category. As Malamud et al. [2004] already pointed out, type 1 inventories can be quite complete if detailed mapping is carried out shortly after the landslide event. On the other hand, in historical landslide inventories, the evidence of the existence of many small-size landslides may be lost due to various degrees of modification. At sea these modifications are mostly induced by hemipelagic sedimentation and erosion, including subsequent landslides. The depositional nature of marine slopes implies that modifications of the sedimentary record and seafloor geomorphology by subsequent processes is less likely and/or takes place at a slower pace than in the subaerial environment, and therefore landslide deposits have a better preservation potential. Accordingly, the potential for compiling a more comprehensive inventory is higher.

[46] Evidence that landslide populations onshore exhibit power law scaling is abundant [e.g., Stark and Hovius, 2001; Malamud et al., 2004]. However, it has been shown that the range of observed power law scaling is limited to a few orders of magnitude [Stark and Hovius, 2001; Guthrie and Evans, 2004; ten Brink et al., 2006; Chaytor et al., 2009], as it is also the case in this study. The scale range over which the power law holds valid might be imposed by the geomorphic system [Stark and Hovius, 2001] through properties such as existence of regional weak layers, pore pressure, and slope angle. Onshore, Guzzetti et al. [2002] found that the "rollover" point at which position the power law fit is no longer valid occurs in relationship to the scale of stream networks, while Stark and Guzzetti [2009] showed that the primary control is the relative importance of cohesion over friction in setting slope stability. Stark and Guzzetti [2009] found that the scaling of smaller, shallower failures results from the low cohesion of soil and regolith, whereas the negative power law-tail scaling for larger failures is tied to the greater cohesion of bedrock. In the Mediterranean Sea the "rollover" occurs at landslide volumes of $1.25 \mathrm{~km}^{3}$ (see Figure $5 \mathrm{a}$ ) and areas of $230 \mathrm{~km}^{2}$. The volume, and particularly the area, of such rollover corresponds to landslides of a relatively large size involving linear dimensions of a few tens of kilometers. This length is much larger than the scale of geomorphological features on submarine canyons, the main element of submarine drainage networks. Also, submarine landslides in our database involve mostly unconsolidated sediment, and therefore, the second hypothesis does not offer a fully satisfactory explanation to the location of the observed rollover point. Other factors, such as early diagenesis, overconsolidation, and slope gradients could perhaps better explain the occurrence of the rollover in our database.

[47] We think that the smaller landslides are undersampled in the database. This undersampling might be due to various reasons, including the difficulties in accessing the marine environment, the resolution of the acoustic mapping methods and/ or their ability to cover areas of significant extent, and also, probably, because larger landslides tend to attract larger interest from researchers and data for these landslides are more often published. Seismic strengthening [Locat and Lee, 2002; Lee et al., 2007] has also been proposed to explain the scarcity of shallow slope failures in active continental margins. The relatively high values of the frequency-magnitude exponent $\theta$ in active margins of the Mediterranean Sea suggest, however, that the scarcity of such slope failures could result from a mapping resolution problem. Also, the volume to area relationship (Figure 3) and the height to runout ratio (Figure 9) for landslides in passive and active margins show similar values. These two indicators suggest that there is no significant difference in dynamic behavior of landslides in active and passive margins. Therefore, there is likely no major difference in rheology from sediments in these two settings that could otherwise result from changes in sediment consolidation and shear strength if seismic strengthening was to play a major role. Widespread occurrence of mass-wasting phenomena in fossil outcrops of the circum-Mediterranean collisional orogenic belts [Pini, 1999, Camerlenghi and Pini, 2009] supports the idea that smaller landslides are undersampled in tectonically active margins.

[48] The methods employed to map the landslides in the database had various resolutions. The area covered by each of those acoustic methods differs significantly, with higher resolution studies covering smaller areas and therefore undersampling smaller events in the database. However, because of the many factors potentially involved in determining the occurrence of the rollover, it is not completely clear whether this rollover may reflect a combination of geologic constraints and mapping resolution or just the latter. Assuming the latter case would imply that the inventory is relatively complete for the range of failures displaying power law behavior. 
[49] In many landscapes, landslides tend to occur where they have occurred in the past. It is also important to remark that, in many parts of the oceans, landslides occur in clusters. A cluster may contain several landslides of different sizes, types, and ages. Landslide coalescence introduces a bias toward the largest failures and is particularly important when identifying submarine landslides using geophysical data. Supposing that (1) the larger landslides in the database could result from coalescing slope failures and that (2) no censoring of smaller landslides due to surveying limitations is present in the database, a lognormal distribution would imply that the landslide catalog is complete over at least 1 more order of magnitude. Droz et al. [2006] and Iribarren et al. [2007] suggest that at least two of the largest submarine landslides could result from amalgamation, and therefore the hypothesis of lognormal behavior cannot be completely ruled out.

[50] The plot in Figure 10 also highlights that the database and our knowledge of submarine landslide distribution with time is limited to a few thousand years. The largest submarine landslides, which have recurrence periods in excess of that interval, seem to be relatively well represented within the database, but it is clear that we are missing critical information to understand the occurrence of, perhaps smaller but relatively more frequent submarine landslides. It is also clear from Figure 11 that the limitations in mapping schemes bias the estimates of the power law scaling exponents. This problem needs to be considered carefully if we want to be able to predict large events [Castillo, 1988] and assess landslide hazard with any accuracy.

\subsection{The Submarine Slope Failure Cycle and Some Insights on Trigger Mechanisms}

[51] The plots in Figures 5 and 11 can be interpreted in a similar way to that of the Gutenberg-Richter relationship in seismology. The $b$ value (the slope of the earthquake frequency-magnitude relationship; analog to our $\theta$ slope or landslide frequency-magnitude exponent) has been reported to vary with the amount of energy dissipation during the rupture events [Yamaguchi et al., 2011]. This energy dissipation depends on many processes such as fault heterogeneity, the stress level imposed on rocks, and pore pressure variations [Marzocchi and Sandri, 2003], the high $b$ values being usually associated with rheologically weak materials and/or high pore pressures [Wiemer and Wyss, 2002]. One could be tempted to draw an analogy with earthquake seismology and interpret the changes in the frequency-magnitude exponent $\theta$ (Table 1 and Figure 5b) resulting from changes in sediment strength and/or pore pressures. However, at least for submarine landslides of the Mediterranean Sea, the lower $\theta$ values are probably associated with the higher pore pressures needed to trigger the slope failures in the relatively seismically quiet passive margins (Regions IV, V, and IX), thus in opposition to the inferences made from seismology. We rather think that the slope of the power fit reflects here the environmental stresses that each region is subject to; therefore, the frequency-magnitude exponent $\theta$ provides information on the prevailing trigger mechanism. High $\theta$ values could indicate high environmental stresses and trigger by earthquakes, while low $\theta$ values would reflect rather low environmental stresses and failure processes dominated by preconditioning factors. The observed $\theta$ values fit well with the idea that sediment deposited by hemipelagic sedimentation and other oceanic processes has a short residence time in active continental margins and that this sediment is mobilized in frequent but smaller landslides to the deep sea. Conversely, on passive margins large sedimentary accumulations tend to build up undisturbed, and, when some minor perturbation occurs (e.g., relatively small earthquake), this sediment is mobilized in large landslides. Frequency-magnitude relationships [Issler et al., 2005; ten Brink et al., 2006, Micallef et al., 2008; Chaytor et al., 2009, Behrmann et al., 2014] and more qualitative analysis [e.g., Mcadoo et al., 2000, Krastel et al., 2006; Micallef et al., 2012] for other areas worldwide indicate that changes in the frequency-magnitude exponent $\theta$ with tectonic setting are global in character.

[52] As shown earlier, most of the flux of landslide material toward the deeper basin is controlled by the largest landslides that occur on passive margins, thus stressing the role of these preconditioning factors. This fact does not preclude that a majority of the landslides could finally be triggered by earthquakes, as reported in section 3.5 (Figure 12), but in passive margins, the final trigger is marginal in controlling onset of slope failure. As said earlier, relatively small earthquakes could actually trigger large-magnitude slope failures if the right set of conditions (most likely related to sedimentation patterns and margin hydrogeology) exist in those margins.

[53] Recent work also suggests that, in opposition to the principles operating in turbidite paleoseismology, the earthquake cycle and recurrence of major mass-wasting phenomena could be disconnected [Strasser et al., 2012; Völker et al., 2011], implying that steady accumulation of sediments and buildup of specific slope conditions is a necessary prerequisite for large submarine landslides to occur. Based on data from the Middle America and Central Chile trench and forearc systems, Behrmann et al. [2014] even suggested that it takes 20 to 200 plate boundary earthquakes to set off a medium-sized $\left(>10 \mathrm{~km}^{2}\right)$ or larger submarine landslide. Figure $4 \mathrm{c}$ shows that the largest Mediterranean submarine slope failures occur in passive margins, where earthquakes of large magnitude are not present and recurrence of intraplate earthquakes is longer than in tectonically active margins. This distribution of slope failures means that, in passive margins, there must be processes at play, other than earthquakes, that precondition the slope for failure and that large slope failures can be triggered with much smaller ground motions (if any at all). The size of these failures also implies relatively homogeneous groundwater conditions over large areas and highlights the significant role that fluids probably play in those failures. Dynamics of these fluids are in turn controlled by changes in both total and effective stresses (i.e., sea level fluctuations in gas and gas hydrate systems [e.g., Kayen and Lee, 1991; Liu and Flemings, 2009; Dondurur et al., 2012; Lafuerza et al., 2012]), bottom water temperature (mainly affecting gas hydrates [e.g., Sultan et al., 2004; Pecher et al., 2005; Nixon and Grozic, 2007]), and, probably most important, the rate of sediment deposition and sedimentation patterns [e.g., Adams and Roberts, 1993; Dugan and Flemings, 2000; Leynaud et al., 2007]. All of the latter are controlled by natural climatic variations [Zhang et al., 2001; Lee, 2009].

[54] The relationship between climate and continental margin hydrogeology has led to considerable debate on the timing within the climate cycle on which submarine slope failure is more likely to occur [e.g., McHugh et al., 2002; Posamentier and Kolla; 2003; Maslin et al., 2004, 
Hühnerbach et al., 2004; Owen et al., 2007] and suggests that the temporal distribution of submarine landslides at scales larger than the Holocene could deviate from that of a Poisson model. Lee [2009] proposes that submarine slope failure is related to climate variations through sediment input, gas hydrate stability, and earthquakes from isostatic readjustments due to ice loading and unloading. Lee [2009] proposes that combined activity of all these factors is maximum during the deglaciation phase, therefore inducing weaker slope conditions during periods of global warming. However, classic sequence stratigraphic analysis and outcrop-derived studies favor slope instability occurrence during lowstands/glaciation [e.g., Flint et al., 2011].

[55] Several authors have highlighted the potential link between gas hydrates and submarine slope instability, although these works do not seem to agree on the timing when those gas hydrates are most likely to influence slope failure. Liu and Flemings [2009] showed that a drop in sea level, without taking into account any climate-driven temperature change, may generate high overpressures and low effective stresses in the free gas zone beneath hydrates, because the high gas compressibility implies that the absolute pore pressure drops much less than the total stress. Sultan et al. [2007] showed that sea level rise induces widespread dissolution at the top of the gas hydrate stability zone, while hydrate dissociation at its bottom due to increasing bottom water temperature is rather a relatively slow process developing on a much smaller portion of the slope. However, as stated earlier, occurrence of gas hydrates in the Mediterranean Sea is limited to a few locations with high interstitial fluid flow rates such as the Nile Delta [Garziglia et al., 2008], the Anaximander mud volcanoes [Woodside et al., 1998], and the Black Sea [Naudts et al., 2006]. Much has been speculated over the occurrence of gas hydrates during glacial maxima, and it seems plausible that the conditions for stability of gas hydrates within the seafloor of the Mediterranean existed only within the deep water portions of the basin [Praeg et al., 2007].

[56] In the passage from the Last Glacial Maximum (LGM) to the current interglacial, Mediterranean Sea surface waters increased their temperatures by $3-6^{\circ} \mathrm{C}$ [Emeis et al., 2000]. Bottom, deep water temperature during the LGM, at least in the Western Mediterranean, was on average $\sim 2{ }^{\circ} \mathrm{C}$ cooler than in the present interglacial, but high-frequency variations (millennial-centennial time scale) involved deep water temperature changes of about $1-2^{\circ} \mathrm{C}$ and in some cases even $4^{\circ} \mathrm{C}$ [Cacho et al., 2006]. Such temperature variations must have had a significant effect in areas where gas hydrates could have existed, particularly the rapid high-frequency variations associated to Dansgaard-Oeschger oscillations. These oscillations could have likely resulted in perturbations of the phase equilibrium of gas hydrates. It should be stressed here that the rate of temperature and pressure (sea level) variation it is probably more important than the sense of this variation, because Dansgaard-Oeschger oscillations were more likely to result in excess pore pressure that could not dissipate rapidly enough.

[57] Nevertheless, evidence that fluid migration occurs in nearby areas where submarine slope failures are present is often cited in the Mediterranean Sea [Woodside et al., 1998; León and Somoza, 2011; Lafuerza et al., 2012; Dondurur et al., 2012]. The seafloor nearby major landslides often shows evidence of fluid expulsion features such as mud volcanoes, e.g., the Great Slide in the Anaximander Mountains [Woodside et al., 1998] or the Rosetta Slide on the Nile fan [Garziglia et al., 2008], and pockmark swarms [Lastras et al., 2004; Minisini et al., 2006]. Also, back analysis of some of the major failures indicates that, in absence of major seismically induced accelerations, at some passive margins large overpressures need to be present at depth for submarine slope failures to be initiated [Urgeles et al., 2006].

[58] Finally, it should be noted also that relatively large earthquakes such as those of higher latitudes due to isostatic rebound in response to glacial loading or unloading [Lee, 2009] are not likely in the Mediterranean region, as ice caps during the Last Glacial Maximum had very limited extension and were confined to the main mountain belts (Alps, Pyrenees, and Caucasus [Ehlers and Gibbard, 2008]).

[59] Timing of slope failure in the database is not easy to interpret in terms of cyclicity and link to natural climate variations. On the one hand, the fact that most of the largest magnitude failures are mobilized during lowstand periods (Figure 10) suggests that pore pressure driven by high sedimentation rates on the slope [e.g., Frigola et al., 2012] and gas exsolution during lowstands could be a major control in slope failure initiation in passive margins. Dissolved gas within interstitial fluids, gas exsolution during lowering of sea level, and pore pressure induced by gas expansion have also been documented as potential mechanisms for triggering submarine landslides [Lafuerza et al., 2012, Dondurur et al., 2012]. Such gas needs to be trapped in shallow reservoirs beneath low-permeability sediments, or it can also be trapped beneath gas hydrates. On the other hand, there are a large number of slope failures that have been attributed a Holocene age and, as said above, with a drape of variable thickness suggesting that failure could have occurred at the beginning of this period, i.e., during transgression, which links to some of the factors pointed out by Lee [2009]. However, there is a clear bias toward younger landslides in the database, as most of the submarine landslides have been mapped from multibeam and shallow geophysical data; thus, we favor that submarine landslides are more likely during lowstand periods.

\subsection{The Inventory of Submarine Landslides of the Mediterranean Sea: Implications for Hazard and Risk Assessment}

[60] Failures greater than $0.1 \mathrm{~km}^{3}$ (relatively large compared to onshore standards) are relatively frequently reported in the margins of the Mediterranean Sea with a mean recurrence interval of $\sim 100$ years. These failures may produce local damage to coastal and offshore infrastructure such as ports, submarine cables, and platforms. Therefore, one could expect that increasing use of the seafloor and exploration activities moving into deeper water may lead to a greater number of incidents. It should be noted, however, that the scale of such phenomena is well suited for detailed assessment of the slope conditions, and therefore well-planned development projects may be able to avoid or mitigate such hazards. Our database presented here, however, is largely biased toward landslide events of large magnitude, and probably these smaller events are much more frequent. Considering that deeper areas beyond the continental slope are most often mapped at a much lower resolution than shallow/coastal waters, the number of relatively small failures should be much 
larger. Indeed, assuming that the power law for Holocene failures can be extrapolated in the range of failures $<1 \mathrm{~km}^{3}$ implies that we should expect one failure larger than $0.1 \mathrm{~km}^{3}$ every $\sim 25$ years, five times more than actually observed.

[61] The relatively good power law fit for landslides larger than $1 \mathrm{~km}^{3}$ (Figure 11) indicates that the catalog is probably complete for failures above that size. Nevertheless, the number of those failures that have been dated with accuracy is still poor. With the largest slope failures occurring at recurrence rates of $\sim 40 \mathrm{kyr}$ (Figure 11), the likelihood of such an event is quite low. However, these events may have an effect at the scale of the whole basin and bear a high tsunamigenic potential regardless of the water depth in which they occur. Uncertainties in these data are, however, extremely large (Figure 11) given the few available dates; hence, results should be taken with caution. Landslides of sizes above $10 \mathrm{~km}^{3}$ may occur more frequently, possibly every $\sim 1 \mathrm{kyr}$, which is within the design period of critical infrastructure such as nuclear power plants. Submarine landslide events of that magnitude can still bear significant tsunamigenic potential at the regional scale, and therefore their probability of occurrence should be carefully considered.

[62] Figures 2 and $4 \mathrm{c}$ show that there is a large disparity in the size of submarine landslides in passive and active continental margins of the Mediterranean Sea. Also, most of the historically well-documented submarine landslides have occurred in the tectonically active margins of Algeria, Liguria, the Gulf of Corinth, Aegean, and Northern Anatolian margin (e.g., EI-Robrini et al. [1985]; Hasiotis et al. [2002]; Rathje et al. [2004]; Cattaneo et al. [2012]; see Papadopoulos et al. [2007] for a historical overview). These are relatively smallsized coastal landslides that are difficult to identify when fully submarine. This issue highlights that the recurrence rate of submarine slope failures is clearly higher in active margins despite the size of these landslides being smaller (Figure 4). Such distribution of submarine landslides between passive and active margins is also highlighted by the steeper slope of the power law relationship (Table 1 and Figures $5 \mathrm{~b}$ and $11 \mathrm{~b}$ ). The effects of such small submarine landslides might still, however, be quite destructive for coastal and offshore infrastructure [EI-Robrini et al., 1985; Mulder et al., 1997; Cattaneo et al., 2012], despite the fact that their tsunamigenic potential is rather limited and of relatively local extent [AssierRzadkiewicz et al., 2000; Rathje et al., 2004; Tinti et al., 2006; Dan et al., 2007; Mazzanti and Bozzano, 2011]. Submarine landslides are less frequent on passive margins of the Mediterranean Sea, but their size is considerably larger (on average 1 order of magnitude larger); this difference implies that their tsunamigenic potential is larger as stated in the previous paragraph. The relatively low recurrence rate that goes beyond historical records in areas such as the Gulf of Valencia, Gulf of Lions, the Nile fan, and the Israeli slope (Figure 2) implies that preparedness and resilience should be carefully evaluated in these areas. The problem is complex because the risk here can be defined as the probability of occurrence of one of these large slope failures (very low) times the impact of its occurrence (very high); therefore, we approach an indeterminate problem of the type $0 \times \infty$. A first action toward understanding whether actual preparedness is adequate or any particular measures need to be undertaken is a probabilistic tsunami hazard assessment from submarine landslides for the Mediterranean Sea in a similar manner to that undertaken for earthquakes [Sørensen et al., 2012]. We believe that the database presented in this study is a first step in this direction.

\section{Conclusions}

[63] The compilation of a catalog of submarine slope failures has provided important insights into the relevance and hazard potential associated with occurrence of submarine slope failures in the Mediterranean Sea, whose vulnerability is extremely high due to the large coastal population and the high density of seabed infrastructures. The catalog presented here is still incomplete, most likely for landslides with a volume less than $1 \mathrm{~km}^{3}$ and in some areas less than $10 \mathrm{~km}^{3}$. Additionally, limited dates for landslides in the database and inability to map extensively below the seafloor imply that the catalog is incomplete both in space and time.

[64] We find that, in the Mediterranean basin, tectonically active margins present numerous but small failures, while passive margins tend to display larger but fewer failures. This pattern of landslide distribution translates into steep slopes of the frequency-magnitude relationship for active margins and gentler slopes for passive margins. The median landslide size in the Mediterranean Sea according to the database is $0.31 \mathrm{~km}^{3}$. Failures in excess of $1000 \mathrm{~km}^{3}$ are only likely to occur in continental margins fed by large river systems, such as the Ebro, Nile, Po, and Rhone at recurrence rates in excess of $40 \mathrm{kyr}$. Transfer of sediment to the deep-sea environment from mass failure is dominated by the fewer large-scale failures rather than multiple smaller landslides. Mass-transport deposits cover $18 \%$ of the Mediterranean seafloor.

[65] In general we observe that for a similar volume range landslides in the Mediterranean Sea have 1 order of magnitude larger runout compared to subaerial landslides. This relationship appears to be valid for landslides of different failure dynamics such as slumps and debris flows. Our analysis of the published literature indicates that there is significant confusion in the terminology used to define landslide processes, and such terminology has important implications for the dynamic behavior of the failed masses. Therefore, there is still a need to standardize the information being published. Generic terms such as mass-transport deposit, mass wasting, and mass failure should be avoided if the main sediment transport process can be inferred from geophysical and sedimentological data. Ideally, the authors should refer to the classification scheme used to denote the mass-transport features observed in their data sets.

[66] Seismic shaking is the most commonly cited cause of offshore slope failure followed by high sedimentation rates and ensuing pore pressure buildup. The fact that a large number of slope failures (a minimum of $25 \%$ ) are related to fluid escape structures such as pockmarks, mud volcanoes, and amplitude anomalies indicates that fluids play a major role in submarine slope instability. A large number of landslides originate in water depths exceeding $1000 \mathrm{~m}$ on slopes $<2^{\circ}$ indicating that the continental rise is a place of high slope instability and suggesting also that flow focusing could be a major control in submarine landslide location.

[67] We know very little on the timing of landslide processes and the relationship with natural climatic variations. In our database only 70 out of 696 MTDs have somewhat accurate age determinations. Very few landslides older than $30 \mathrm{ka}$ have been dated, but those available suggest that the 
largest failures occur in lowstand periods. However, many more landslides have been tentatively dated with an epoch. Taking those into account, we suggest that climate-induced stress changes (sedimentary load, sea level, bottom temperature effect on fluid flow, gas hydrate, and gas systems) during the deglaciation phase, even at low latitudes, may have a significant effect on submarine slope stability.

[68] Failures greater than $0.1 \mathrm{~km}^{3}$, which can produce damage to coastal and offshore infrastructure, have a mean recurrence interval of $\sim 100$ years. Extrapolating power law behavior in that magnitude range implies, however, that failures of that size could be 5 times more frequent. Landslides of moderate magnitude $\left(>10 \mathrm{~km}^{3}\right)$, which may bear significant tsunamigenic potential, may recur every $\sim 1 \mathrm{kyr}$; hence a probabilistic assessment of the tsunami hazard should be the next step to undertake.

[69] Acknowledgments. We acknowledge the support of the Spanish Ministry of Science and Innovation (MICINN) through National Project HADES (CTM2011-30400-C02-01 and CTM2011-30400-C02-02), the EC for support through the EUROFLEETS initiative to the SALTFLU cruise operated by OGS, and UNESCO and IUGS for support through project IGCP585. This work has been carried out within Grups de Recerca de la Generalitat de Catalunya B-CSI (2009 SGR 146). A.C. has worked on this manuscript with funding from Flagship Project RITMARE. L. Fantoni and F. Palmer contributed to the database construction. J. Chaytor, S. Gulick, an anonymous reviewer, Associate Editor W. Kim, and Editor A. Densmore have provided stimulating reviews.

\section{References}

Adams, C. E., and H. H. Roberts (1993), A model of the effects of sedimentation rate on the stability of Mississippi Delta sediments, Geo-Mar. Lett., 13, 17-23, doi:10.1007/BF01204388.

Antony, A., L. Cittadini, R. Karrenberg, R. Kisteleki, T. Refice, T. Vest, and R. Wilhelm (2008), Mediterranean fiber cable cut (January-February 2008) analysis of network dynamics, Technical Report RT-DIA-1242008, University of Rome, Italy.

Assier-Rzadkiewicz, S., P. Heinrich, P. C. Sabatier, B. Savoye, and J. F. Bourillet (2000), Numerical modelling of a landslide-generated tsunami: The 1979 Nice event, Pure Appl. Geophys., 157, 1717-1727, doi:10.1007/PL00001057.

Basili, R., et al. (2013), The European Database of Seismogenic Faults (EDSF) compiled in the framework of the Project SHARE, http://diss. rm.ingv.it/share-edsf/, doi:10.6092/INGV.IT-SHARE-EDSF.

Behrmann, J.-H., D. Völker, J. Geersen, R. Harders, and W. Weinrebe (2014), Size-frequency relationship of submarine landslides at convergent plate margins: Implications for hazard and risk assessment, in Submarine Mass Movement and Their Consequences, Advances in Natural and Technological Hazards Research, vol. 37, edited by S. Krastel et al., pp. 165-175, Springer, Dordrecht (The Netherlands), doi:10.1007/978-3-319-00972-815.

Berndt, C., S. Costa, M. Canals, A. Camerlenghi, B. De Mol, and M. Saunders (2012), Repeated slope failure linked to fluid migration: The Ana submarine landslide complex, Eivissa Channel, Western Mediterranean Sea, Earth Planet. Sci. Lett., 319-320, 65-74, doi:10.1016/j.eps1.2011.11.045.

Billi, A., R. Funiciello, L. Minelli, C. Faccenna, G. Neri, B. Orecchio, and D. Presti (2008), On the cause of the 1908 Messina tsunami, southern Italy, Geophys. Res. Lett., 35, L06301, doi:10.1029/2008GL033251.

Bryn, P., A. Solheim, K. Berg, R. Lien, C. F. Forsberg, H. Haflidason, D. Ottesen, and L. Rise (2003), The Storegga Slide Complex: Repeated large scale sliding in response to climatic cyclicity, in Submarine Mass Movements and Their Consequences, Advances in Natural and Technological Hazards Research, vol. 19, edited by J. Locat and J. Mienert, pp. 215-222, Kluwer Acad. Publ, Dordrecht, The Netherlands.

Cacho, I., N. Shackleton, H. Elderfield, F.-J. Sierro, and J. Grimalt (2006), Glacial rapid variability in deep-water temperature and $\delta^{18} \mathrm{O}$ from the Western Mediterranean Sea, Quat. Sci. Rev., 25, 3294-3311, doi:10.1016/ j.quascirev.2006.10.004.

Calvert, A., E. Sandvol, D. Seber, M. Baranzangi, S. Roecker, T. Mourabit, F. Vidal, G. Alguacil, and N. Jabour (2000), Geodynamic evolution of the lithosphere and upper mantle beneath the Alborán region of the western Mediterranean: Constraints from travel time tomography, J. Geophys. Res., 105, 10,871-10,898.

Camerlenghi, A., and G. A. Pini (2009), Mud volcanoes, olistostromes, and argille scagliose in the Mediterranean Region, Sedimentology, 56, 319-365, doi:10.1111/j.1365-3091.2008.01016.x.
Castillo, E. (1988), Extreme Value Theory in Engineering, Academic Press Inc., San Diego, CA, USA.

Cattaneo, A., N. Babonneau, G. Ratzov, G. Dan-Unterseh, K. Yelles, R. Bracène, B. Mercier de Lépinay, A. Boudiaf, and J. Déverchère (2012), Searching for the seafloor signature of the 21 May 2003 Boumerdès earthquake offshore central Algeria, Nat. Hazards Earth Syst. Sci., 12, 2159-2172, doi:10.5194/nhess-12-2159-2012.

Chaytor, J. D., U. S. ten Brink, A. R. Solow, and B. D. Andrews (2009), Size distribution of submarine landslides along the U.S. Atlantic margin, Mar. Geol., 264, 16-27, doi:10.1016/j.margeo.2008.08.007.

Chiocci, F. L., C. Romagnoli, P. Tommasi, and A. Bosman (2008), The Stromboli 2002 tsunamigenic submarine slide: Characteristics and possible failure mechanisms, J. Geophys. Res., 113, B10102, doi:10.1029/ 2007JB005172.

CIESM/Ifremer Medimap Group, et al (2008), Morpho-bathymetry of the Mediterranean Sea, Commission International pour 1'Etude Scientifique de la Méditerranée, Monaco.

Clauset, A., C. R. Shalizi, and M. E. J. Newman (2009), Power-law distributions in empirical data, SIAM Rev., 51, 661-703, doi:10.1137/070710111.

Dan, G., N. Sultan, and B. Savoye (2007), The 1979 Nice harbour catastrophe revisited: Trigger mechanism inferred from geotechnical measurements and numerical modelling, Mar. Geol., 245, 40-64, doi:10.1016/j. margeo.2007.06.011.

De Blasio, F. V., A. Elverhøi, L. Engvik, D. Issler, P. Gauer, and C. Harbitz (2006), Understanding the high mobility of subaqueous debris flows, Norw. J. Geol., 86, 275-284.

Della Vedova, B., G. Pellis, A. Camerlenghi, J. P. Foucher, and F. Harmegnies (2003), Thermal history of deep-sea sediments as a record of recent changes in the deep circulation of the eastern Mediterranean, J. Geophys. Res., 108(C9), 8110, doi:10.1029/2002JC001402.

Dondurur, D., H. Mert Küçük, and G. Çifçi (2012), Quaternary mass wasting on the western Black Sea margin, offshore of Amasra, Global Planet. Change, 103, 248-260, doi:10.1016/j.gloplacha.2012.05.009.

Droz, L., A. T. dos Reis, M. Rabineau, S. Berné, and G. Bellaiche (2006), Quaternary turbidite systems on the northern margins of the Balearic Basin (Western Mediterranean): A synthesis, Geo-Mar. Lett., 26, 347-359, doi:10.1007/s00367-006-0044-0.

Dugan, B., and P. B. Flemings (2000), Overpressure and fluid flow in the New Jersey continental slope: Implications for slope failure and cold seeps, Science, 289, 288-291, doi:10.1126/science.289.5477.288.

Ehlers, J., and P. Gibbard (2008), Extent and chronology of Quaternary glaciation, Episodes, 31, 211-218.

EI-Robrini, M., M. Gennesseaux, and A. Mauffret (1985), Consequences of the EI-Asnam earthquakes: Turbidity currents and slumps on the Algerian margin (Western Mediterranean), Geo-Mar. Lett., 5, 171-176, doi:10.1007/BF02281635.

Emeis, K.-C., U. Struck, H.-M. Schulz, R. Rosenberg, S. Bernasconi, H. Erlenkeuser, T. Sakamoto, and F. Martínez-Ruix (2000), Temperature and salinity variations of Mediterranean Sea surface waters over the last 16,000 years from records of planktonic stable oxygen isotopes and alkenone unsaturation ratios, Palaeogeogr. Palaeoclimatol. Palaeoecol., 158, 259-280, doi:10.1016/S0031-0182(00)00053-5.

European Environment Agency (1999), State and pressure of the marine and coastal Mediterranean environment, Environmental issues series, 5, Copenhagen, Denmark.

Flint, S. S., D. M. Hodgson, R. Brunt, A. Prelat, W. C. Van der Merwe, J. Figueiredo, C. Di Celma, and J. P. Kavanagh (2011), Depositional architecture and sequence stratigraphy of the Karoo basin floor to shelf edge succession, Laingsburg Depocentre, South Africa, Mar. Pet. Geol., 28, 658-674, doi:10.1016/j.marpetgeo.2010.06.008.

Frey Martinez, J., J. Cartwright, and B. Hall (2005), 3D seismic interpretation of slump complexes: Examples from the continental margin of Israel, Basin Res., 17, 83-108, doi:10.1111/j.1365-2117.2005.00255.x.

Frigola, J., et al. (2012), A 500 kyr record of global sea-level oscillations in the Gulf of Lion, Mediterranean Sea: New insights into MIS 3 sea-level variability, Clim. Past, 8, 1067-1077, doi:10.5194/cp-8-1067-2012.

Garziglia, S., S. Migeon, E. Ducassou, L. Loncke, and J. Mascle (2008), Mass-transport deposits on the Rosetta province (NW Nile deep-sea turbidite system, Egyptian margin): Characteristics, distribution, and potential casual processes, Mar. Geol., 250, 180-198, doi:10.1016/j. margeo.2008.01.016.

Geist, E. L., J. D. Chaytor, T. Parsons, and U. ten Brink (2013), Estimation of submarine mass failure probability from a sequence of deposits with age dates, Geosphere, 9, 287-298, doi:10.1130/GES00829.1.

Gillespie, C. S. (2013), Fitting heavy tailed distributions: The poweRlaw package. $\mathrm{R}$ package version 0.20 .1 .

Gràcia, E., J. Dañobeitia, J. Vergés, R. Bartolomé, and D. Córdoba (2003), Crustal architecture and tectonic evolution of the Gulf of Cadiz (SW Iberian margin) at the convergence of the Eurasian and African plates, Tectonics, 22(4), 1033, doi:10.1029/2001TC901045. 
Guthrie, R. H., and S. G. Evans (2004), Magnitude and frequency of landslides triggered by a storm event, Loughborough Inlet, British Columbia, Nat. Hazards Earth Syst. Sci., 4, 475-483, doi:10.5194/nhess-4-475-2004.

Guzzetti, F., B. D. Malamud, D. L. Turcotte, and P. Reichenbach (2002), Power-law correlations of landslide areas in Central Italy, Earth Planet. Sci. Lett., 195, 169-183, doi:10.1016/S0012-821X(01)00589-1.

Guzzetti, F., F. Ardizzone, M. Cardinalli, M. Rossi, and D. Valigli (2009), Landslide volumes and landslide mobilization rates in Umbria, central Italy, Earth Planet. Sci., 279, 222-229, doi:10.1016/j.eps1.2009.01.005.

Haflidason, H., R. Lien, H. P. Sejrup, C. F. Forsberg, and P. Bryn (2005), The dating and morphometry of the Storegga Slide, Mar. Pet. Geol., 22, 123-136, doi:10.1016/j.marpetgeo.2004.10.008.

Hampton, M. A., H. J. Lee, and J. Locat (1996), Submarine landslides, Rev. Geophys., 34, 33-59, doi:10.1029/95RG03287.

Harbitz, C. B., F. Løvholt, G. Pedersen, and D. G. Masson (2006), Mechanisms of tsunami generation by submarine landslides: A short review, Norw. J. Geol., 86, 249-258.

Hasiotis, T., G. Papatheodorou, G. Bouckovalas, C. Corbau, and G. Ferentinos (2002), Earthquake-induced coastal sediment instabilities in the western Gulf of Corinth, Greece, Mar. Geol., 186, 319-335, doi:10.1016/S0025-3227(02)00240-2.

Hergarten, S. (2003), Landslides, sandpiles, and self-organized criticality, Nat. Haz. Earth Sys. Sci., 3, 505-514, doi:10.5194/nhess-3-505-2003

Hovius, N., C. Stark, and P. Allen (1997), Sediment flux from a mountain belt derived by landslide mapping, Geology, 25, 231-234, doi:10.1130/ 0091-7613(1997)025<0231:SFFAMB $>2.3$.CO;2

Hühnerbach, V., D. G. Masson, and partners of the COSTA project (2004), Landslides in the North Atlantic and its adjacent seas: An analysis of their morphology, setting and behaviour, Mar. Geol., 213, 343-362, doi:10.1016/j.margeo.2004.10.013.

Iribarren, L., J. Vergés, F. Camurri, J. Fullea, and M. Fernàndez (2007), The structure of the Atlantic-Mediterranean transition zone from the Alboran Sea to the Horseshoe Abyssal Plain (Iberia-Africa plate boundary), Mar. Geol., 243, 97-119, doi:10.1016/j.margeo.2007.05.011.

Issler, D., F. V. De Blasio, A. Elverhoi, P. Bryn, and R. Lien (2005), Scaling behavior of clay-rich submarine debris flows, Mar. Pet. Geol., 22, 187-194, doi:10.1016/j.marpetgeo.2004.10.015

Jolivet, L., and J.-P. Brun (2010), Cenozoic geodynamic evolution of the Aegean, Int. J. Earth Sci., 99, 109-138, doi:10.1007/s00531-008-0366-4.

Kayen, R. E., and H. J. Lee (1991), Pleistocene slope instability of gas hydrate laden sediment on the Beaufort Sea margin, Mar. Geotech., 10, 125-141, doi:10.1080/10641199109379886.

Korup, O., T. Görüm, and Y. Hayakawa (2012), Without power? Landslide inventories in the face of climate change, Earth Surf. Process. Landforms, 37, 92-99, doi:10.1002/esp.2248.

Krastel, S., R. B. Wynn, T. J. J. Hanebuth, R. Henrich, C. Holz, H. Meggers, H. Kuhlmann, A. Georgiopoulou, and H. D. Schulz (2006), Mapping of seabed morphology and shallow sediment structure of the Mauritania continental margin, Northwest Africa: Some implications for geohazard potential, Norw. J. Geol., 86, 163-176.

Laberg, J. S., and T. O. Vorren (2000), The Trænadjupet Slide, offshore Norway-Morphology, evacuation and triggering mechanisms, Mar. Geol., 171, 95-114, doi:10.1016/S0025-3227(00)00112-2.

Lafuerza, S., N. Sultan, M. Canals, G. Lastras, A. Cattaneo, J. Frigola, S. Costa and C. Berndt (2012), Failure mechanisms of Ana Slide from geotechnical evidence, Eivissa Channel, Western Mediterranean Sea, Mar. Geol., 307-310, 1-21, doi:10.1016/j.margeo.2012.02.0102012.

Larsen, I. J., D. R. Montgomery, and O. Korup (2010), Landslide erosion controlled by hillslope material, Nat. Geosci., 3, 247-251, doi:10.1038/ NGEO776.

Lastras, G., M. Canals, R. Urgeles, J. E. Hughes-Clarke, and J. Acosta (2004), Shallow slides and pockmark swarms in the Eivissa Channel Western Mediterranean Sea, Sedimentology, 51, 1-14, doi:10.1111/ j.1365-3091.2004.00654.x.

Lastras, G., M. Canals, D. Amblas, J. Frigola, R. Urgeles, A. M. Calafat, and J. Acosta (2007), Slope instability along the northeastern Iberian and Balearic continental margins, Geol. Acta, 5, 35-47, doi:10.1344/ 105.000000308 .

Lee, H. J. (2009), Timing of occurrence of large submarine landslides on the Atlantic Ocean margin, Mar. Geol., 264, 53-64, doi:10.1016/j. margeo.2008.09.009.

Lee, H. J., J. Locat, P. Desgagnés, J. Parson, B. McAdoo, D. Orange, P. Puig, F. Wong, P. Dartnell, and É. Boulanger (2007), Submarine mass movements on continental margins, in Continental-Margin Sedimentation: From Sediment Transport to Sequence Stratigraphy (Special Publication 37 of the IAS), edited by C. A. Nittrouer et al., 213-274, Blackwell Publishing, Malden, MA, USA

León, R., and L. Somoza (2011), GIS-based mapping for marine geohazards in seabed fluid leakage areas (Gulf of Cadiz, Spain), Mar. Geophys. Res., 32, 207-223, doi:10.1007/s11001-011-9135-z.
Leynaud, D., N. Sultan, and J. Mienert (2007), The role of sedimentation rate and permeability in the slope stability of the formerly glaciated Norwegian continental margin: The Storegga slide model, Landslides, J. Int Consortium on Landslides, 4, 297-309, doi:10.1007/s10346-007-0086-Z. Liu, X., and P. B. Flemings (2009), Dynamic response of oceanic hydrates to sea level drop, Geophys. Res. Lett., 36, L17308, doi:10.1029/2009GL03982. Locat, J. (2001), Instabilities along ocean margins: A geomorphological and geotechnical perspective, Mar. Pet. Geol., 18, 503-512, doi:10.1016 S0264-8172(00)00076-3

Locat, J., and H. J. Lee (2002), Submarine landslides: Advances and challenges, Can. Geotech. J., 39, 193-212, doi:10.1139/t01-089.

Lofi, J., J. Déverchère, V. Gaullier, H. Gillet, C. Gorini, P. Guennoc, L. Loncke, A. Maillard, F. Sage, and I. Thinon (2011), Seismic atlas of the "Messinian Salinity Crisis" markers in the Mediterranean and Black Seas, vol. 179, Commission for the Geological Map of the World and Mémoires de la Société Géologique de France.

Malamud, B. D., D. L. Turcotte, F. Guzzetti, and R. Reichenbach (2004), Landslide inventories and their statistical properties, Earth Surf Process Landforms, 29, 687-711, doi:10.1002/esp.1064.

Marzocchi, W., and L. Sandri (2003), A review and new insights on the estimation of the $b$-value and its uncertainty, Ann. Geophys., 46, 1271-1282, doi:10.4401/ag-3472.

Maslin, M., M. Owen, S. Day, and D. Long (2004), Linking continentalslope failures and climate change: Testing the clathrate gun hypothesis, Geology, 32, 53-56, doi:10.1130/G20114.1.

Masson, D. G. (1994), Late Quaternary turbidity current pathways to the Madeira Abyssal Plain and some constraints on turbidity current mechanisms, Basin Res., 6, 17-33, doi:10.1111/j.1365-2117.1994.tb00072.x.

Masson, D. G., C. B. Harbitz, R. B. Wynn, G. Pedersen, and F. Løvholt (2006), Submarine landslides-Processes, triggers and hazard prediction, Phil. Trans. R.. Soc. London A, 364, 2009-2039, doi:10.1098/rsta.2006.1810.

Mazzanti, P., and F. Bozzano (2011), Revisiting the February 6th 1783 Scilla (Calabria, Italy) landslide and tsunami by numerical simulation, Mar Geophys. Res., 32, 273-286, doi:10.1007/s11001-011-9117-1.

McAdoo, B. G., L. F. Pratson, and D. L. Orange (2000), Submarine landslide geomorphology, US continental slope, Mar. Geol., 169, 103-136, doi:10.1016/S0025-3227(00)00050-5.

McHugh, C. M. G., J. E. Damuth, and G. S. Mountain (2002), Cenozoic mass-transport facies and their correlation with relative sea-level change, New Jersey continental margin, Mar. Geol., 184, 295-334, doi:10.1016/ S0025-3227(01)00240-7.

Meier, T., M. Rische, B. Endrun, A. Vafidis, and H.-P. Harjes (2004), Seismicity of the Hellenic subduction zone in the area of western and central Crete observed by temporary local seismic networks, Tectonophysics, 383, 149-169, doi:10.1016/j.tecto.2004.02.004

Micallef, A., C. Berndt, D. G. Masson, and D. A. V. Stow (2008), Scale invariant characteristics of the Storegga Slide and implications for largescale submarine mass movements, Mar. Geol., 247, 46-60, doi:10.1016/ j.margeo.2007.08.003.

Micallef, A., J. J. Mountjoy, M. Canals, and G. Lastras (2012), Deep-seated bedrock landslides and submarine canyon evolution in an active tectonic margin: Cook Strait, New Zealand, in Submarine Mass Movements and Their Consequences, Advances in Natural and Technological Hazard Research, vol. 31, edited by Y. Yamada et al., pp. 201-212, Springer, Dordrecht, The Netherlands, doi: 10.1007/978-94-007-2162-3 18

Minisini, D., F. Trincardi, and A. Asioli (2006), Evidence of slope instability in the Southwestern Adriatic Margin, Nat. Hazards Earth Syst. Sci., 6 , 1-20, doi:10.5194/nhess-6-1-2006.

Moernaut, J., and M. De Batist (2011), Frontal emplacement and mobility of sublacustrine landslides: Results from morphometric and seismostratigraphic analysis, Mar. Geol., 285, 29-45, doi:10.1016/j.margeo.2011.05.001.

Mohrig, D., K. X. Whipple, M. Hondzo, C. Ellis, and G. Parker (1998), Hydroplaning of subaqueous debris flow, Geol. Soc. Am. Bull., 110 387-394, doi:10.1130/0016-7606(1998)110<0387:HOSDF > 2.3.CO;2.

Mulder, T., and P. Cochonat (1996), Classification of offshore mass movements, J. Sediment. Res., 66, 43-57, doi:10.1306/D42682AC2B26-11D7-8648000102C1865D

Mulder, T., B. Savoye, and J. P. M. Syvitski (1997), Numerical modelling of a mid-sized gravity flow: The 1979 Nice turbidity current (dynamics, processes, sediment budget and seafloor impact), Sedimentology, 44, 305-326, doi:10.1111/j.1365-3091.1997.tb01526.x.

Mulder, T., and J. Alexander (2001), The physical character of subaqueous sedimentary density flows and their deposits, Sedimentology, 48, 269-299, doi:10.1046/j.1365-3091.2001.00360.x.

Nardin, T. R., F. J. Hein, D. S. Gorsline, and B. D. Edwards (1979), A review of mass movement processes and acoustic characteristics, and contrasts in slope and base-of-slope systems versus canyon-fan-basin floor systems, in Geology of Continental Slopes, SEPM Special Publication, vol. 27, edited by L. J. Doyle and O. H. Pilkey, pp. 61-73, Society of Economic Paleontologists and Mineralogists, Tulsa, Oklahoma, USA. 
Naudts, L., J. Greinert, Y. Artemov, P. Staelens, J. Poort, P. Van Rensbergen, and M. De Batist (2006), Geological and morphological setting of 2778 methane seeps in the Dnepr paleo-delta, northwestern Black Sea, Mar. Geol., 227, 177-199, doi:10.1016/j.margeo.2005.10.005.

Nixon, M. F., and J. L. H. Grozic (2007), Submarine slope failure due to gas hydrate dissociation: A preliminary quantification, Can. Geotech. J., 44 314-325, doi:10.1139/T06-121.

Okal, E. A., and C. E. Synolakis (2004), Source discriminants for near-field tsunamis, Geophys. J. Int., 158, 899-912, doi:10.1111/j.1365-246X.2004.02347.x.

Owen, M., S. Day, and M. Maslin (2007), Late Pleistocene submarine mass movements: Occurrence and causes, Quat. Sci. Rev., 26, 958-978, doi:10.1016/j.quascirev.2006.12.011.

Papadopoulos, G. A., E. Daskalaki, and A. Fokaefs (2007), Tsunamis generated by coastal and submarine landslides in the Mediterranean Sea, in Submarine Mass Movements and Their Consequences, Advances in Natural and Technological Hazards Research, vol. 28, edited by V. Lykousis, D. Sakellariou, and J. Locat pp. 415-422, Springer, Dordrecht, The Netherlands, doi:10.1007/978-1-4020-6512-5 43

Pecher, I. A., S. A. Henrys, S. Ellis, S. M. Chiswell, and N. Kukowski (2005), Erosion of the seafloor at the top of the gas hydrate stability zone on the Hikurangi Margin, New Zealand, Geophys. Res. Lett., 32, L24603, doi:10.1029/2005GL024687.

Perissoratis, C., and G. Papadopoulos (1999), Sediment instability and slumping in the southern Aegean Sea and the case history of the 1956 tsunami, Mar. Geol., 161, 287-305, doi:10.1016/S0025-3227(99)00039-0.

Pillans, B., J. Chappell, and T. R. Nash (1998), A review of the Milankovitch climatic beat: Template for Plio-Pleistocene sea-level changes and sequence stratigraphy, Sediment. Geol., 122, 5-21, doi:10.1016/S0037-0738(98)00095-5.

Pini, G. A. (1999), Tectonosomes and olistostromes in the Argille Scagliose of the Northern Apennines, Italy, Geol. Soc. Am. Spec. Pap., 335, 1-70, doi:10.1130/0-8137-2335-3.1.

Posamentier, H. W., and V. Kolla (2003), Seismic geomorphology and stratigraphy of depositional elements in deep-water settings, J. Sediment Res. 73, 367-388, doi:10.1306/111302730367

Praeg, D., V. Unnithan, and A. Camerlenghi (2007), Gas hydrate stability in the Mediterranean Sea over glacial-interglacial timescales: Results from the HYDRAMED project, in Geo-Marine Research Along European Continental Margins-International Conference and Post-Cruise Meeting of the Training-Through-Research Programme (TTR16), IOC Workshop Report No. 204, pp. 36-37, UNESCO, Intergovernmental Oceanographic Commission, Bremen, Germany.

R Core Team (2012), R: A language and environment for statistical computing. $\mathrm{R}$ Foundation for Statistical Computing, Vienna, Austria. ISBN 3-900051-07-0, URL http://www.R-project.org/.

Rathje, E., I. Karatas, S. G. Wright, and J. Bachhuber (2004), Coastal failures during the 1999 Kocaeli earthquake in Turkey, Soil Dyn. Earthquake. Eng., 24, 699-712, doi:10.1016/j.soildyn.2004.06.003.

Roca, E., M. Sans, L. Cabrera, and M. Marzo (1999), Oligocene to Middle Miocene evolution of the central Catalan margin (northwestern Mediterranean), Tectonophysics, 315, 209-229, doi:10.1016/S0040-1951 (99)00289-9.

Rothwell, R. G., M. S. Reeder, G. Anastasakis, D. A. V. Stow, J. Thomson, and G. Kahler (2000), Low sea-level stand emplacement of megaturbidites in the western and eastern Mediterranean Sea, Sediment. Geol., 135, 75-88, doi:10.1016/S0037-0738(00)00064-6.

Royden, L. H. (1993), Evolution of retreating subduction boundaries formed during continental collision, Tectonics, 12, 629-638, doi:10.1029/92TC02641.

Salamon, A., T. Rockwell, S. N. Ward, E. Guidoboni, and A. Comastri (2007), Tsunami hazard evaluation of the Eastern Mediterranean: Historical analysis and selected modeling, B. Seismol. Soc.Am., 97, 705-724, doi:10.1785/ 0120060147.

Schattner, U., and B.- Z. Avraham (2007), Transform margin of the northern Levant, eastern Mediterranean: From formation to reactivation, Tectonics, 26, TC5020, doi:10.1029/2007TC002112.

Sørensen, M. B., M. Spada, A. Babeyko, S. Wiemer, and G. Grünthal (2012), Probabilistic tsunami hazard in the Mediterranean Sea, J. Geophys. Res., 117, B01305, doi:10.1029/2010JB008169.

Stark, C. P., and F. Guzzetti (2009), Landslide rupture and the probability distribution of mobilized debris volumes, J. Geophys. Res., 114 F00A02, doi:10.1029/2008JF001008.

Stark, C. P., and N. Hovius (2001), The characterization of landslide size distributions, Geophys. Res. Lett., 28, 1091-1094, doi:10.1029/2000GL008527.

Stigall, J., and B. Dugan (2010), Overpressure and earthquake initiated slope failure in the Ursa Region, Northern Gulf of Mexico, J. Geophys. Res., 115, B04101, doi:10.1029/2009JB006848.

Strasser, M., P. Henry, T. Kanamatsu, M. K. Thu, G. F. Moore, and the IODP Expedition 333 Scientists (2012) Scientific drilling of mass-transport deposits in the Nankai accretionary wedge: First results from IODP Expedition 333, in Submarine Mass Movements and Their Consequences, Advances in Natural and Technological Hazard Research, vol. 31, edited by Y. Yamada et al., pp. 671-681, Springer, Dordrecht, The Netherlands, doi:10.1007/978-94-007-2162-3 60 .

Sultan, N., P. Cochonat, J. P. Foucher, and J. Mienert (2004), Effect of gas hydrate melting on seafloor slope stability, Mar. Geol., 231, 379-401, doi:10.1016/j.margeo.2004.10.015

Sultan, N., M. Voisset, T. Marsset, A. M. Vernant, E. Cauquil, J. L. Colliat, and V. Curinier (2007), Detection of free gas and gas hydrate based on 3D seismic data and cone penetration testing: An example from the Nigerian Continental Slope, Mar. Geol., 240(1-4), 235-255, doi:10.1016 j.margeo.2007.02.012

Tanaka, H., and J. Locat (1999), A microstructural investigation of Osaka Bay clay: The impact of microfossils on its mechanical behaviour, Can Geotech. J., 36, 493-508, doi:10.1139/t99-009.

ten Brink, U. S., E. L. Geist, and B. D. Andrews (2006), Size distribution of submarine landslides and its implication to tsunami hazard in Puerto Rico, Geophys. Res. Lett., 33, L11307, doi:10.1029/2006GL026125.

ten Brink, U. S., R. Barkan, B. D. Andrews, and J. D. Chaytor (2009), Size distributions and failure initiation of submarine and subaerial landslides, Earth Planet. Sci. Lett., 287, 31-42.

Tinti, S., A. Armigliato, A. Manucci, G. Pagnoni, F. Zaniboni, A. C. Yalciner, and Y. Altinok (2006), The generating mechanisms of the August 17, 1999 Izmit bay (Turkey) tsunami: Regional (tectonic) and local (mass instabilities) causes, Mar. Geol., 225, 311-330, doi:10.1016/j.margeo.2005.09.010.

Trincardi, F., and A. Argnani (1990), Gela submarine slide: A major basinwide event in the Plio-Quaternary foredeep of Sicily, Geo-Mar. Lett., 10, 13-21, doi:10.1007/BF02431017.

Urgeles, R. (2012), Fluid flow focusing in passive continental margins: Significance to submarine slope instability, in Landslides and Engineered Slopes: Protecting Society Through Improved Understanding, edited by E. Eberhardt et al., pp. 73-82, CRC Press, Leiden, The Netherlands.

Urgeles, R., M. Canals, and D. G. Masson (2001), Flank stability and processes off the western Canary Islands: A review, Sci. Mar., 65, 21-32.

Urgeles, R., D. Leynaud, G. Lastras, M. Canals, and J. Mienert (2006), Backanalysis and failure mechanisms of a large submarine slide on the Ebro continental slope, NW Mediterranean, Mar. Geol., 226, 185-206, doi:10.1016/j.margeo.2005.10.004

Urgeles, R., J. Locat, and B. Dugan (2007), Recursive failure of the Gulf of Mexico continental slope: Timing and causes, in Submarine Mass Movements and Their Consequences, Advances in Natural and Technological Hazards Research, vol. 27, edited by V. Lykoussis, D. Sakellariou, and J. Locat pp. 209-219, Springer, Dordrecht, The Netherlands, doi:10.1007/978-1-4020-6512-5_22.

Urlaub, M., P. J. Talling, and D. G. Masson (2013), Timing and frequency of large submarine landslides: Implications for understanding triggers and future geohazard, Quat. Sci. Rev., 72, 63-82, doi:10.1016/j. quascirev.2013.04.020

Vannucci, G., S. Pondrelli, A. Argnani, A. Morelli, P. Gasperini, and E. Boschi (2004), An atlas of Mediterranean seismicity, Ann. Geophys. Suppl. V., 47(1), 247-306, doi:10.4401/ag-3276.

Vanoudheusden, E., N. Sultan, and P. Cochonat (2004), Mechanical behaviour of unsaturated marine sediments: Experimental and theoretical ap proaches, Mar. Geol., 213, 323-342, doi:10.1016/j.margeo.2004.10.012.

Varnes, D. J. (1978), Slope movement types and processes, in Landslides, Analysis and Control, Transportation Research Board Sp. Rep. No. 176 edited by R. L. Schuster and R. J. Krizek, pp. 11-33, Nat. Acad. of Sciences, Washington D.C., USA

Venables, W. N., and B. D. Ripley (2002), Modern Applied Statistics with S, 4th ed., pp. 495, Springer, New York, NY, USA.

Völker, D., F. Scholz, and J. Geersen (2011), Analysis of submarine landsliding in the rupture area of the 27 February 2010 Maule earthquake, Central Chile, Mar. Geol., 288, 79-89, doi:10.1016/j.margeo.2011.08.003.

Volpi, V., A. Camerlenghi, C.-D. Hillenbrand, M. Rebesco, and R. Ivaldi (2003), Effects of biogenic silica on sediment compaction and slope stability on the Pacific margin of the Antarctic Peninsula, Basin Res., 15, 339-363, doi:10.1046/j.1365-2117.2003.00210.x.

Vuong, Q. H. (1989), Likelihood ratio tests for model selection and nonnested hypotheses, Econometrica: J.. Econometric Soc., 57, 307-333.

Ward, S. N. (2001), Landslide tsunami, J. Geophys. Res., 106, 11,201-11,215, doi:10.1029/2000JB900450

Watts, P., S. T. Grilli, J. T. Kirby, G. J. Fryer, and D. R. Tappin (2003), Landslide tsunami case studies using a Boussinesq model and a fully nonlinear tsunami generation model, Nat. Hazards Earth Syst. Sci., 3, 391-402, doi:10.5194/nhess-3-391-2003.

Wiemer, S., and M. Wyss (2002), Mapping spatial variability of the frequency-magnitude distribution of earthquakes, Adv. Geophys., 45, 259-302, doi:10.1016/S0065-2687(02)80007-3.

Woodside, J. M., M. K. Ivanov, A. F. Limonov, and Shipboard Scientists of the Anaxiprobe Expeditions (1998), Shallow gas and gas hydrates in the Anaximander Mountains region, eastern Mediterranean Sea. in Gas 


\section{URGELES AND CAMERLENGHI: LANDSLIDES IN THE MEDITERRANEAN SEA}

Hydrates: Relevance to World Margin Stability and Climate Change, Geological Society of London, Special Publications, vol. 137, edited by J.-P. Henriet and J. Mienert, pp. 177-193, Geological Society of London, U. K., doi:10.1144/GSL.SP.1998.137.01.15.

Yamaguchi, T., M. Morishita, M. Doi, T. Hori, H. Sakaguchi, and J.-P. Ampuero (2011), Gutenberg-Richter's law in sliding friction of gels, J. Geophys. Res., 116, B12306, doi:10.1029/2011JB008415.
Zhang, P. Z., P. Molnar, and W. R. Downs (2001), Increased sedimentation rates and grain sizes 2-4Myr ago due to the influence of climate change on erosion rates, Nature, 410, 891-897, doi:10.1038/ 35073504.

Zitter, A. C. T., J. M. Woodside, and J. Mascle (2003), The Anaximander Mountains: A clue to the tectonics of southwest Anatolia, Geol. J., 38, 375-394, doi:10.1002/gj.961. 